\title{
AGRARIAN FEATURES, FARMSTEADS, AND HOMESTEADS IN THE RÍO BEC NUCLEAR ZONE, MEXICO
}

\author{
Eva Lemonnier ${ }^{\mathrm{a}}$ and Boris Vannière ${ }^{\mathrm{b}}$ \\ aUniversité Paris 1-Panthéon-Sorbonne, CNRS, UMR 8096 Archéologie des Amériques, 21 allée de l'Université, F-92023, \\ Nanterre Cedex, France \\ ${ }^{\mathrm{b}} \mathrm{CNRS}$, UMR 6249, 16 route de Gray F-25030, Besançon Cedex, France
}

\begin{abstract}
With its overall settlement pattern more dispersed than those of other contemporary Maya sites, and many associated land use features still preserved, the spatial layout of the Río Bec nuclear zone (159 ha) leads us to give priority to the hypothesis of a production economy based on infield agriculture. Through a multidisciplinary and multiscalar research strategy, including several geoarchaeological methods developed on three different spatial scales, it is possible to forward a model of territorial occupation and land use for the Río Bec apogee period (A.D. 700-850). Geographical and archaeological data, along with chronological and spatial analyses, allow us to reconstruct a built field system made up of distinct agricultural production units. From a socioeconomic perspective, the model suggests that agricultural production was managed at the household scale and that each unit or farmstead was distinct and autonomous from its neighbors.
\end{abstract}

For the past 60 years, the societal-environmental relationship particular to the Southern Maya Lowlands has been debated (Coe and Flannery 1964; Flannery 1982; Harrison and Turner 1978; Netting 1977; Sanders 1977; Turner and Sanders 1992; Wauchope 1956; Willey 1956; Willey et al. 1965), with one specific topic focusing on the emergence and dynamics of urbanization and its collapse in the ninth century (Arnauld and Michelet 2004; Drennan 1988; Dunning et al. 2002; Hodell et al. 1995; Johnston and Breckenridge 1999; Leyden et al. 1996; Rice 1993; Whitmore and Turner 2001). The archaeological, geomorphological, and botanical studies of pre-Columbian Maya agriculture focus upon techniques, forms, and structures of landscaping, spatial patterns of land use, and ecological impact delineating models of agricultural intensification and diversification (Fedick 1996a; Gómez Pompa et al. 2003; Johnston 2003; Killion 1992; Liendo Stuardo 2002; Ross 2011; Turner 1983). Some multidisciplinary studies have sought to analyze the global land-use pattern on the ground, taking into account not just spaces, soils, and water resources, but also land improvements, farming techniques, and even the nature of cultigens (Chase and Chase 1998; Dunning et al. 1997; Fedick 1994, 1996b; Webster et al. 2000:153-174). The large-scale spatial approaches that attempt to outline the field system organization, however, often fall short of their goal.

The organization of the Río Bec dwellings does not follow a structural pattern characteristic of an urban site. Instead, the dispersion of houses associated with multiple terraces that shape the landscape first suggests a rather rural configuration. Unlike most lowland Classic Maya cities, there are no house concentrations

E-mails correspondence to: evalemonnier11@gmail.com around a politico-religious center that likely served as the seat of a royal dynasty (Adams 1981; Adams and Jones 1981; Carrasco Vargas et al. 1986; Merwin 1913; Ruppert and Denison 1943; Thomas 1981). Although they served both private and public functions, even the most monumental edifices were essentially residential. Instead of expressing functional differences, morphological variation-from simple houses in perishable materials on a masonry platform up to the monumental residences in Río Bec architectural style-more probably reflects a strong social hierarchy within the settlement (see Arnauld et al. 2013; Nondédéo et al. 2013). As documented by the pedestrian survey previous to the research we report in this article, however, the spatial distribution does not show concentrations of lower rank dwellings around higher rank residences that, taken together, would suggest the existence of neighborhoods (Arnauld et al. 2012; Lemonnier and Arnauld 2008), and regular dispersion seems to have been the rule. In our study zone, the residential density can be estimated at about 200 structures $/ \mathrm{km}^{2}$ (Arnauld et al. 2013; Nondédéo et al. 2013), which is in the lower range of typical densities for Classic Maya sites (150 to 400 structures $/ \mathrm{km}^{2}$ ), whether made up of neighborhoods or not (Drennan 1988:278-280).

Furthermore, during the project's initial survey (Michelet 2004; Nondédéo 2002), the intermediate spaces between houses proved significantly modified by numerous human-made landscape changes that are still clearly visible on surface. These consisted, in particular, of terraces similar to those recognized regionally since the $1970 \mathrm{~s}$ (Carrasco Vargas et al. 1986; Turner 1974, 1983), as well as stone berms or ridges also identified in large numbers at other Río Bec-style sites like Becan (Thomas 1981), Chicanna (Carrasco Vargas et al. 1986), Xpujil (Pollock 1967), and Hormiguero (Peña Castillo 1987). Although other more common features in the Maya 
area such as aguadas and stone quarries for construction can be visually identified, these Río Bec sites are distinguished from other large contemporary Maya settlements by the way dwellings appear distributed and structured. While this could partly reflect a hierarchical society without local centralized powers, it may also result from an intraresidential agricultural production economy. Drennan (1988: 284-290) showed that a fairly regular dispersion and a settlement average density might be explained by an intensive infield-type agriculture $^{1}$ practiced around the houses. All these characteristics lead us to forward the hypothesis that it was primarily the agrarian system that determined both the form and structure of settlement at Río Bec, as well as how it functioned at a local scale. Subsequently, this initial form of organization would have favored and produced social differentiation and local powers, the latter with an archaeological expression different than we see at other sites.

This hypothesis was tested in the context of the Río Bec Sub-Project VIII (Lemonnier and Vannière 2008, 2009; Vannière et al. 2006, 2007), which is dedicated to the study of the built environment. The objective is to reconstruct an environmental spatial pattern coherently accounting for the site's geomorphologic character and land resources. The idea that components of the humanly modified landscape detectable on surface are evidence of ancient infield agriculture-sufficiently intensified to be still discerned and described a millennium after having been abandonedguided us. As the Río Bec forest was largely unoccupied after Classic/Epiclassic period times, there are good grounds for accepting that the ancient land management had left perceptible traces in the microtopography of the forest soils and land surface. For the period of Río Bec apogee (Makan phase, A.D. 700-850), the aim of the study was to identify the forms and ways in which the local space was organized and managed, to evaluate to what extent it was transformed, and to define the characteristics of the spaces thus created. The method utilized consists of measuring the construction of the landscape so as to place the associated dwellings back into their geomorphologic environment, probably characterized by some sort of field system, and hence, a land tenure organization.

\section{GEOGRAPHICAL SETTING}

Río Bec, the eponymous site of a Maya region known for its decorated monumental architecture, is located in the heart of the Yucatan peninsula (Campeche, Mexico). Archaeologically, the Río Bec region lies between the Chenes and Puuc regions (to the north) and the Peten (to the south). Located less than $25 \mathrm{~km}$ to the north, the sites of Becan, Xpujil, and Chicanna are the closest to Río Bec. The major sites of Calakmul and Oxpemul are located $50-60 \mathrm{~km}$ to the southwest. Geographically, Río Bec is situated on a vast limestone plateau approximately $260 \mathrm{~m}$ asl. Rendzinatype soils predominate and the hydrographic network is mainly karstic. The nearest water sources are several kilometers distant from the nuclear zone (see below): to the north the small "Río Bec" stream, and $30 \mathrm{~km}$ to the southeast are the lakes Ohm, El Barranco, and Chakanbakan. The climate type is warm and tropical wet with dry winters alternating with summer rainy seasons. The vegetation is a tropical monsoon, evergreen forest, with an average height of 20-30 m, in which Manilkara sapota (the sapodilla) predominates.

${ }^{1}$ According to Turner and Sanders (1992:266) "[i]nfields and outfields constitute spaces cultivated primarily with the major staple crops, the former closer to the main farming abode than the latter."
The area's detailed geography reveals two main geomorphologic units alternating high zones, or interfluves, separated by low zones, or talwegs. The talwegs, with more or less steep slopes and more or less deep clayey soils, represent the drainage axes and are mostly oriented south-west/north-east. Some low flat zones form seasonal swamps (bajos) that isolate the interfluves. The latter are characterized by vast, gently rolling surfaces. Pedology indicates that they have shallow $(25-50 \mathrm{~cm})$ but well-drained soils. Wholly similar, soil profiles show two horizons, an hA clay-silt horizon quite rich in organic matter and an $\mathrm{h}(\mathrm{B}) / \mathrm{C}$ horizon corresponding to the limestone bedrock's degradation level. In the lower-lying zones specific profiles are more developed, including an intermediate "illuvial" $\mathrm{hB}$ horizon rich in clay, and in some local places vertic soils can be found. But there is actually very low variability in soil profiles and characteristics within our working area, where calcareous rendzina and vertic soils prevail. The anthropic structures are found almost exclusively on the interfluves.

\section{METHODS}

Our work developed within the Río Bec project area (Figure 1) called the "nuclear zone," which covers approximately 159 ha, and was initially surveyed in 2002-2003 by Nondédéo (2002) and Michelet (2004). It is founded on a multidisciplinary and multiscalar research strategy. Three methodological approaches were used (Figure 2): (a) high and very high resolution microtopographical surveys, (b) excavations in a representative sample of the recorded archaeological structures, and test pits in the identified intermediate spaces, and (c) intensive and systematic pedestrian surveys over a larger research window to broaden the range of observations. Within the nuclear zone, the research areas were selected for the diversity of their natural relief features (talweg, interfluves, steep slopes, pre-existing man-made alterations), the morphological and dimensional variation among structures (ridges, terraces, chultunes, large and small buildings, quarries), and among intermediate spaces (circumscribed flat zones, hollowed out zones). Another criterion was the location of the project excavations in residential clusters with monumental architecture (Groups A, B, C and D) (see Arnauld et al. 2013; Michelet et al. 2013). Micro-topographical survey and archaeological excavations, including test pits in the intermediate spaces, were done in an eight hectare research zone named "Zone 8." In the center of Zone 8, a half-hectare "Zoom Zone" including several characteristic structures was analyzed at very high spatial resolution $(1 \mathrm{~m})$. The results of these combined methods in the Zoom Zone allow us to define a pattern of spatial organization that was then extrapolated to Zone 8. Lastly, this pattern was tested and validated through a pedestrian survey over the wider area of a third research zone covering 33 ha called "Zone 33." In addition, 9 ha around Group A were studied through the same techniques. Sub-Project VIII total area covers 50 ha $(31.5 \%$ of the 159 ha Río Bec nuclear zone).

\section{Micro-topographical Surveys}

The micro-topographic approach is based on survey with an infrared electronic tacheometer (Leica TC307 total station) and reflector using conventional polygonation, with establishment of a northsouth base and allocation of UTM coordinates to the point of origin: UTM zone $1116, X=250619 \pm 5 \mathrm{~m}, \mathrm{Y}=032864 \pm 5 \mathrm{~m}$, $\mathrm{Z}=261 \pm 5 \mathrm{~m}$ (coord. WS geo: $18^{\circ} 22^{\prime} 15.9^{\prime \prime} \mathrm{N}, 89^{\circ} 21^{\prime} 36.6^{\prime \prime} \mathrm{W}$ 

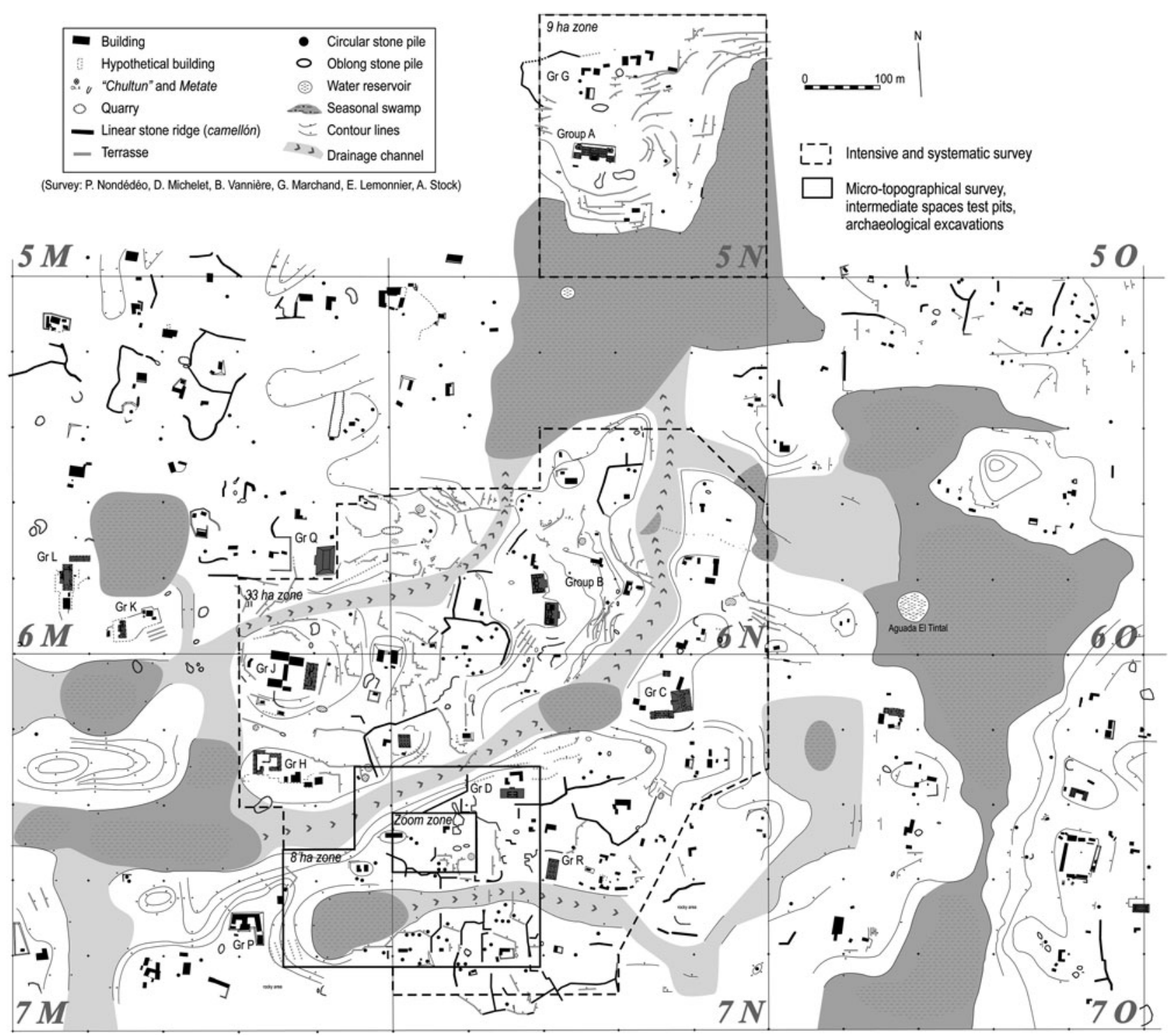

Figure 1. The Río Bec nuclear zone (Campeche, Mexico), with the location of the 50 ha area studied in relation with the agrarian issue. Survey and drawing by Philippe Nondédéo, Dominique Michelet, Boris Vannière, Guy Marchand, Eva Lemonnier, and Agnès Stock.

GPS Garmin map 76 with WAAS). Overall the number of topographic points measured was 13,296 (a density of one point every $6 \mathrm{~m}^{2}$ ). In the Zoom Zone alone, the survey included 4,259 points (a density of one point every $1.25 \mathrm{~m}^{2}$ ). In both cases, the point's precision is $30 \mathrm{~cm}$ for the $\mathrm{X}$ and $\mathrm{Y}$ axes, and $5 \mathrm{~cm}$ for the $\mathrm{Z}$ elevation measurements. The data were next treated and mapped with a GIS program (ARCGIS 9) able to create first a Triangular Interpolation Network (TIN) and then a Digital Terrain Model (DTM) map through interpolation of the natural neighbors needed for slope analysis. These micro-topographic surveys allowed us to propose a morphological typology of all anthropic structures and identified intermediate spaces, and then to sample them for testing by means of pits and trenches.

\section{Archaeological Excavations}

The archaeological excavations aimed to describe precisely the nature and determine the function of the various types of structures visible on surface, while giving priority to non-residential structures. The objective was to establish a typology from the morphological and functional data obtained. We also collected the necessary chronological data for the spatial analysis of the research zone at large (up to the 50 ha scale). A total of 27 structures were excavated, half in the Zoom Zone with 39 units and trenches, including one entirely cleared house with low walls built of stone. Except the quarries, every defined structural type was excavated, yet we gave priority to two types: the remains of dwellings partially constructed in perishable materials, and stone or rubble piles-two types difficult to separate and interpret without excavating. Differentiating them, though, has direct and important demographic implications for the whole project area. The stone quarries-a priori reserved for the building of masonry dwellings-were studied as part of the lithic analysis undertaken by Chloé Andrieu, and research on construction techniques conducted by Céline Gillot (Andrieu 2008, 2009; Andrieu and Gillot 2008; Gillot 2010). As for the intermediate spaces, 30 test pits $(1 \times 1.5 \mathrm{~m})$ were dug in 


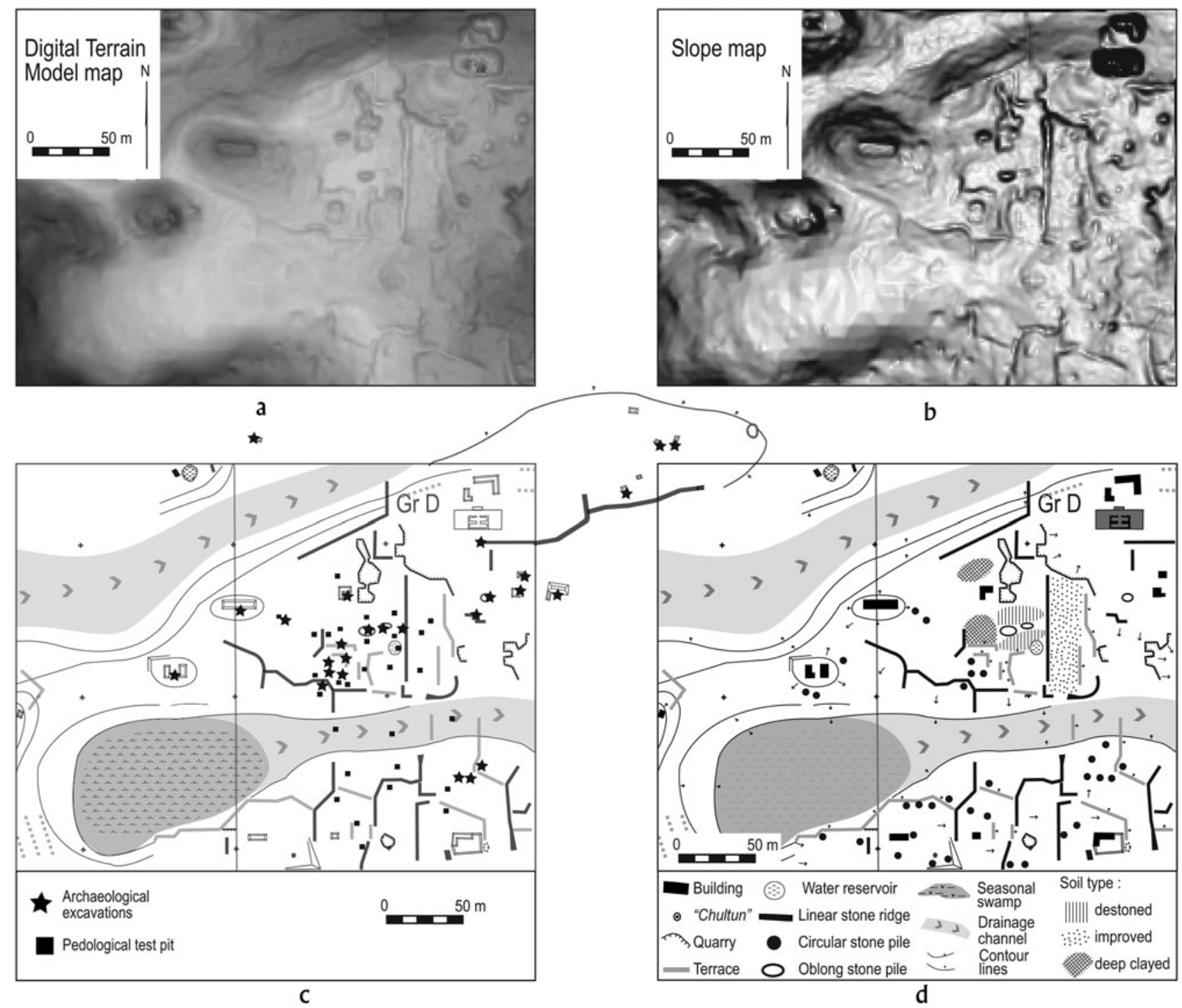

Figure 2. Micro-topographical, archaeological and pedological survey within the 8 ha zone. (a) Digital Terrain Model map; (b) Slope map; (c) Map of the archaeological excavations (black stars) and pedological test pits (black squares); (d) Interpretation map. Maps by Boris Vannière and Eva Lemonnier.

Zone 8 in order to evaluate the nature of the soils, their depth, stoniness, and associated archaeological artifacts, as well as to find indicators of anthropogenic impact on soil linked with specific agricultural techniques, such as improving soil by spreading domestic waste, or modifying texture (Guilaine 1991; Hayden and Cannon 1983; Killion et al. 1989; Smyth et al. 1995).

\section{Pedestrian Survey}

The intensive and systematic surveys of Zone 33 and the 9 ha area around Group A tested and amplified the results obtained in Zone 8 and the Zoom Zone, thereby enabling us to reconstruct elements of a system of spatial organization and management over a larger area. The chronological diagnostics (test of contemporaneity) for the identified structures and land modifications are based on the ceramic chronology expertise of Sara Dzul (ceramics included from all types of excavations).
Two functional units are used to develop a model of territorial occupation (Figure 2): the Household Unit (HU) (see Ashmore 1981; Robin 2003) and the Agrarian Production Unit (APU). The first is defined on the basis of house morphology and spatial layout (including direct distance analysis); the second on the same parameters applied to adjacent non-residential structures.

\section{RESULTS}

The micro-topographic and archaeological findings provide an image of a highly anthropized environment; for example, a built landscape organized upon the natural relief as modified by humans (Figure 3). First, a high density of structures marks the interfluves, while the talwegs seem to have none. Second, on the interfluves some features, particularly rectilinear structures, quite clearly compartmentalize space (Figures $2 \mathrm{a}$ and $2 \mathrm{~b}$ ). The third characteristic of the Río Bec landscape is the wide diversity of its 


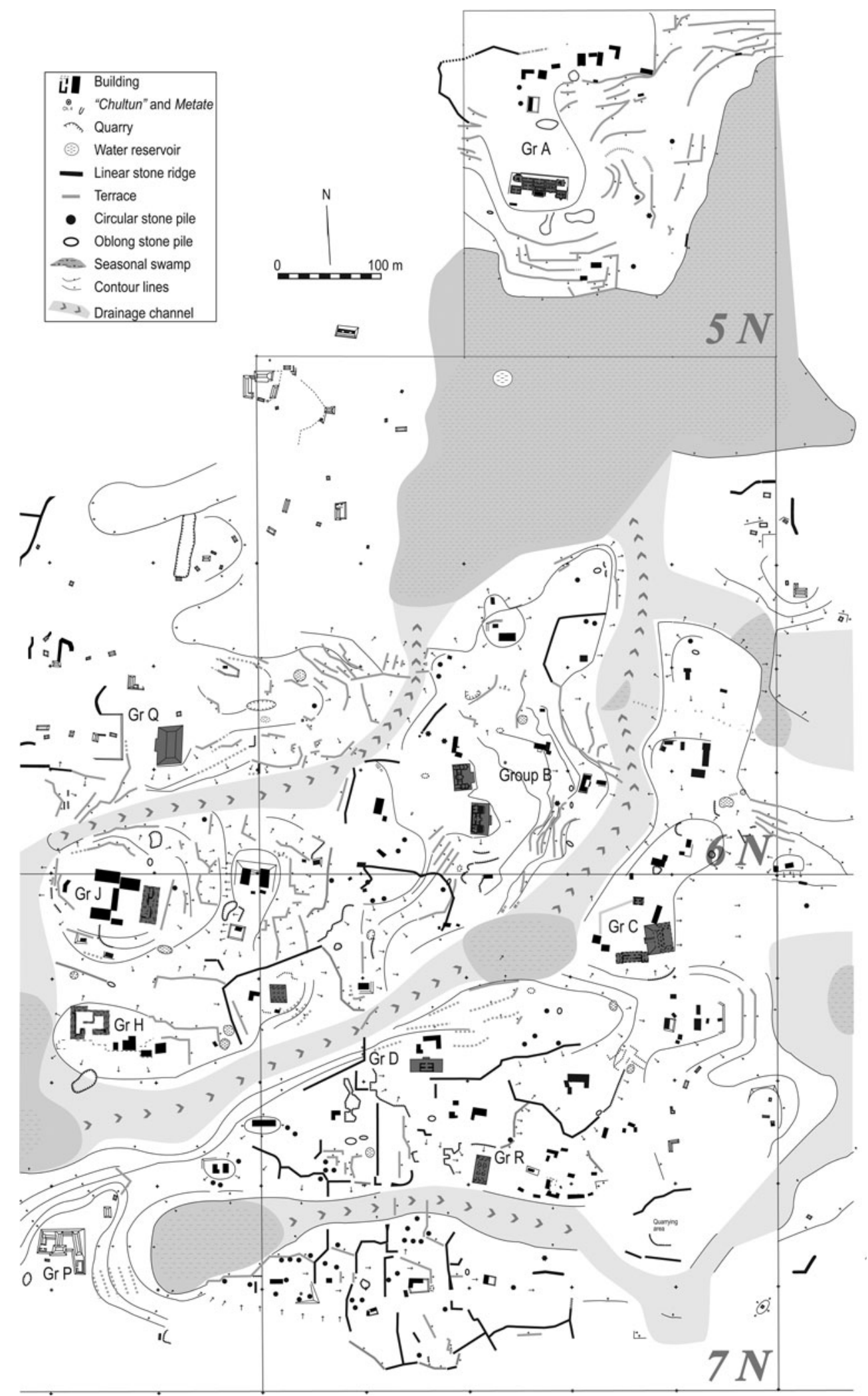

Figure 3. Results from surveys and excavations in the 8 ha ("Zone 8"), 33 ha ("Zone 33"), and 9 ha areas around Group A (2005-2008), Río Bec nuclear zone. Drawings by Boris Vannière and Eva Lemonnier. 
Table 1. Quantities of structures recorded within the Río Bec nuclear zone (including 10 terraces identified by Thomas [1976])

\begin{tabular}{|c|c|c|c|c|c|c|c|}
\hline \multirow{2}{*}{$\begin{array}{l}\text { Structures } \\
\text { Zones }\end{array}$} & \multirow{2}{*}{ Quarry } & \multirow{2}{*}{ Aguada } & \multirow{2}{*}{ Terrace } & \multirow{2}{*}{ Ridge } & \multicolumn{2}{|c|}{ Stone piles } & \multirow{2}{*}{ Total } \\
\hline & & & & & Oblong TP2 & Circular TP1 & \\
\hline Zones 8 and 33 (41 ha) & 26 & 8 & 118 & 13 & 19 & 62 & 246 \\
\hline Group A (9 ha) & 4 & 0 & 40 & 3 & 1 & 6 & 54 \\
\hline $\begin{array}{l}\text { Nuclear zone except Group A, } \\
\text { Zones } 8 \text { and } 33 \text { (109 ha) }\end{array}$ & 45 & 5 & 17 & 72 & 12 & 53 & 204 \\
\hline TOTAL (159 ha) & 75 & 13 & 175 & 88 & 32 & 121 & 504 \\
\hline
\end{tabular}

anthropic structures. On the basis of data series from excavations and ground observations, all structures have been identified and classified according to size, form, surface composition, artifacts, and location. The presence/absence of vaulted roof and decorated features has been considered as an additional criterion in establishing the hierarchy of house mounds. House hierarchy ranges widely from small, low rectangular platforms to high multiroom vaulted houses (types M9 to M3; see Nondédéo et al. 2013:Table 5). Apart from these residential structures, six morphological and functional categories have been defined: quarries, reservoirs (aguadas), terraces, linear stone ridges, and two types of stone piles (oblongand circular-shaped piles). These six categories comprise 300 structures in the $\mathbf{5 0}$ ha area studied (Table 1 ). They add as many negative as positive salient features on surface, producing new axes that organize the landscape in relation to its natural geomorphology, and at a smaller scale they partly control the surface water runoff. Chronologically, almost all excavated structures-one reservoir, two terraces, three ridges, and four oblong-shaped piles-yielded ceramics characteristic of the Late Classic period (Kanlol [A.D. 550-700] and Makan [A.D. 700-850] phases). Out of the six low-rank dwellings studied in Zone 8 (Units 7N64, 7N114, 7M27, 7N16, 7N63, 7N14; the last four including one vaulted structure each), only one was abandoned fairly early in the Late Classic period (with no ceramics later than the Kanlol phase). Only the circular-shaped pile type (10 piles excavated) predates this period, dating between the Early Classic and the early Late Classic (Iximche [A.D. 425-550] and Kanlol) phases. Thus, most of the structures would be contemporary with Río Bec at its apogee, with the exception of a probable large number of circular piles.

The 45 HUs located in the 50 ha study area each include at least one lone house, or one house with a separate kitchen (Arnauld et al. 2013; Nondédéo et al. 2013). In the unit hierarchy established by Arnauld and colleagues (2013) for the nuclear zone, 10 of the 45 units are assigned Rank I to Rank III, each one including at least one Río Bec-style monumental building; 24 to Ranks IV-V, each with at least one vaulted residence; and, 11 to Rank VI, with one unvaulted house (rarely two). The six excavated houses in Zone 8 are assigned to Rank V units.

Quarries were studied briefly as part of our research. Dug from the limestone bedrock, they are numerous and quite variable in form and dimensions (ranging from 3-50 $\mathrm{m}$ in length). Some obviously separated two neighboring HUs. Others might have acquired a secondary function after being used, perhaps as water collectors and reservoirs, although no specific modification has been detected.

Reservoirs (aguadas) vary in dimension, as well. The most imposing (tens of meters in diameter) are located in swamps outside the 50 ha study area. They were dug in clayey soils suitable for retaining rainwater, and controlling infiltration. Their anthropogenic nature is beyond doubt: several are still bordered with stones. The radiocarbon dating from charcoal obtained in backfill sediments are subsequent to the site's main occupation (post-cal A.D. 1000, $2 \sigma$ ). They evidence the permanent maintenance of these waterholes in Río Bec's heyday (Vannière et al. 2006). The smallest reservoirs are located close to the dwellings on the interfluves. One of them, a few meters wide, was investigated in the Zoom Zone. A radiocarbon date of $1000 \pm 30$ B.P. (cal A.D. 980-1060, 2 $\sigma$ ) from charcoal taken from the base of its infill provides an indication of its abandonment (Vannière et al. 2006), which was likely in the early Early Postclassic period, a little later than the abandonment of Río Bec monumental residences dated to the Xpuhuk 1 (A.D. 850-900) or Xpuhuk 2 (A.D. 900-1000) phase (see Taladoire et al. 2013). This late occupation has not been identified in the immediate surroundings for lack of diagnostic ceramics (for example, Tohil Plumbate was only found in Group B). It is possible that occupation lasted, however, until about A.D. 1100 without major changes in Xpuhuk wares.

Terraces are made up of two components; the retaining wall (embankment) and the actual terrace or plot (Figure 4). Walls were built directly on the sloping bedrock following the angle of inclination. They are oblique, fairly wide (up to $2 \mathrm{~m}$ ) and relatively high (averaging .5-1 m). They are composed of an infill of small stones between two rudimentary stonewalls no higher than $30 \mathrm{~cm}$, sometimes made up of large blocks. The lower wall supports the infill while the upper one edges the plot. The terrace plots are strips of mostly narrow land ( $2 \mathrm{~m}$ on average) when compared to their length, which can reach tens of meters. The terrace earth fill is thick (30-50 cm deep), cleared of stones, and protected from erosion by the upper retaining wall. The wide embankment fills in breaks in the bedrock slope so as to create level, potentially cultivable areas. But in some locations, even spaces with practically no relief were terraced, especially around Group D. In contrast, around Group B, terraces have been laid on steep slopes. Slope angles were not systematically measured over Zone 33, yet a large variation can be assessed with terraces on slopes from $2^{\circ}$ to more than $20^{\circ}$ (the latter south to Group K).

Without a doubt, the most conspicuous structure type is the linear stone ridge. These are generally very long (up to $50 \mathrm{~m}$ in the studied zone), narrow (4-5 m wide) and often high $(.5-2 \mathrm{~m}$ tall) with a rounded top (Figure 5). Our excavations have shown that they are piles of stones built either on the paleosoil or on earlier backfilled occupation remains. They are edged at their base by a string of stones forming a low rudimentary retaining wall similar to those of the terraces. Technically, these long and voluminous structures constitute the simplest land management feature, but certainly also the most durable. They are still very visible today and 


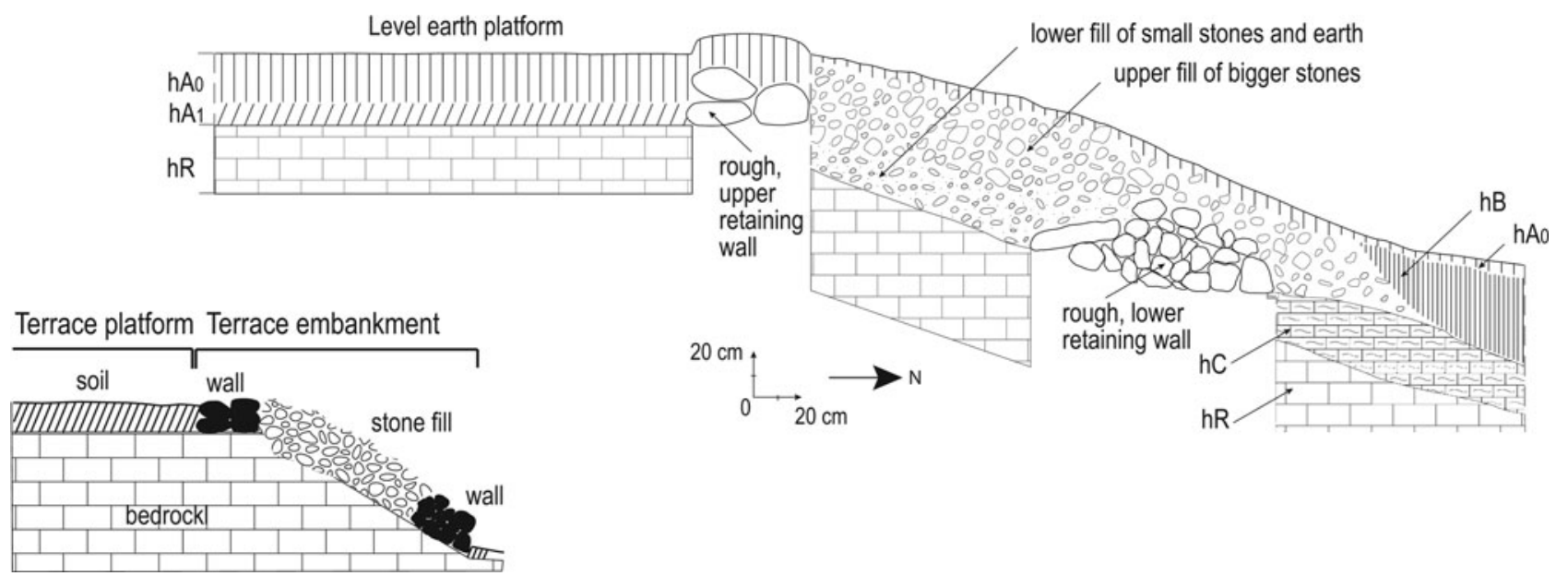

Figure 4. Agricultural terrace, cross section and sketch (7N-TER9), Río Bec nuclear zone. Drawing by Eva Lemonnier.

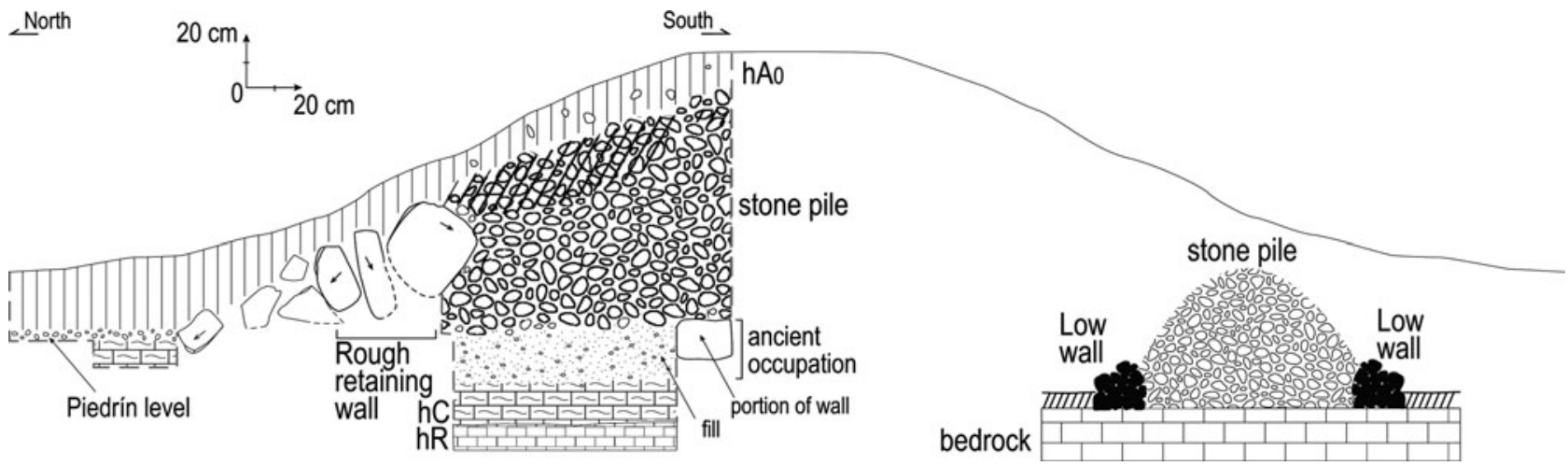

Figure 5. Linear stone ridge, cross section and sketch (7N-CAM 5), Río Bec nuclear zone. Drawing by Eva Lemonnier.

must have been even more so when in use. The fact that their infill consists of stones without soil retained by low walls, as well as the fact that some of them run close to houses, allows us to discard the hypothesis that they supported substantial vegetation or particular cultigens. The origin of such large quantities of stones is unknown, although quarry waste and evidence of stone clearing on some plots could provide partial answers. Lastly, many are oriented in a cardinal direction that, together with their dimensions, lead us to interpret them as "stone barriers" used to demarcate space, as well as controlling the drainage of rainwater (see below).

In the stone pile category, as mentioned, two classes must be defined: (1) oblong-shaped stone piles (coded TP2 in the Río Bec structure typology; see Nondédéo et al. 2013: Table 6) (see Figure 6); and, (2) circular-shaped stone piles (coded TP1) (Figure 7). Superficially, the former are difficult to distinguish from mounds left by Rank VI (the lowest) dwellings. But following

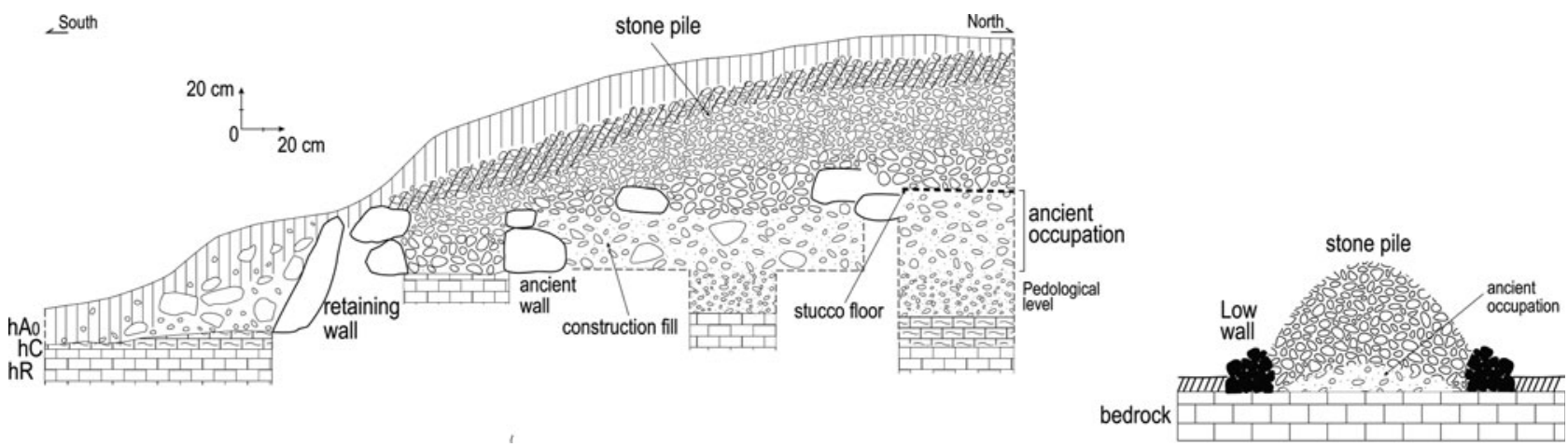

Figure 6. Oblong-shaped stone pile, cross section (7N-18), Río Bec nuclear zone. Drawing by Eva Lemonnier. 

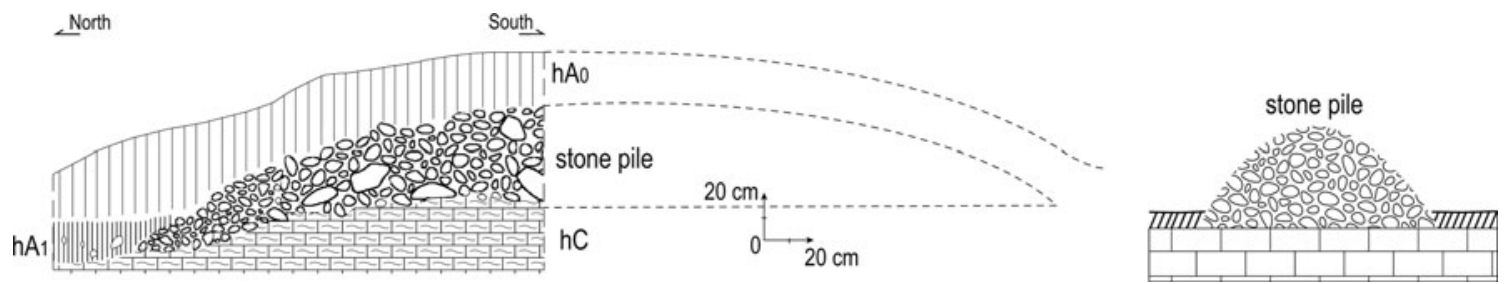

Figure 7. Circular-shaped stone pile, cross section and sketch (7N-109), Río Bec nuclear zone. Drawing by Eva Lemonnier.

excavation, they clearly differ in content. The four oblong piles that were excavated revealed a stone fill contained by a crude low retaining wall built in much the same way as the edges of terraces and ridges. The heap is made up of layers of stones of different sizes-larger below, smaller above-possibly indicating continuous, progressive construction linked to some specific activity. All four excavated cases cover an earlier occupation level. For example, vestiges of stucco floors and masonry walls, poorly defined in our limited excavations, date to the Late Preclassic (Bohom phase [300 B.C.-A.D. 300]) or Early Classic (Iximche phase [A.D. 450-550) periods based on associated ceramics, yet the piles themselves date, at the earliest, to the Kanlol phase (identified by sherds exclusively diagnostic of the Kanlol phase) and, at the latest, to the Makan phase. Their perimeters exceed that of the remains they cover so that their extremities rest on the bedrock or paleosoil. The dimensions of these piles vary from $8-11 \mathrm{~m}$ in length, $2-5 \mathrm{~m}$ in width, and .6-1.1 $\mathrm{m}$ in height.

The circular-shaped piles are smaller with less variable dimensions, most less than $2 \mathrm{~m}$ in diameter (although some are up to $5 \mathrm{~m}$ ), and less than $1 \mathrm{~m}$ high, often down to $.5 \mathrm{~m}$. They are thus difficult to locate in the forest environment. As mentioned above, circular piles appear to be earlier than most other features (Iximche-Kanlol phase). Data from the excavations of 10 circular piles indicate the stone fill is not contained by a wall and shows one single layer with no interstitial earth fill. Lying directly on the bedrock, they do not appear to cover any vestige of an earlier occupation.

Considering their morphology, dating, and spatial distribution, we interpret the oblong piles as heaps of stones cleared out of soil and, in some cases at least, as reserves of construction material; many of them probably also served to cover earlier vestiges. The circular piles would represent the altered remains of earlier residential or agricultural structures (see below).

One particular structure excavation is worth mentioning. In the Zoom Zone, an M4-type platform with no superstructure (7M24) was trenched at one end and in the middle. This large, low, flat mound revealed itself to be the platform built for a long superstructure of the multiroom residence type (M9 or M8) with its long central and rear walls solidly built into the fill, but never raised above the platform level. It is probably one of a number of Río Bec residences that exhibits a building process interrupted at some point (Michelet et al. 2013).

The 30 test pits located in the intermediate spaces were concentrated in our Zoom Zone (covering .5 ha). These allowed us to observe the variability in stones and sherds contained within the soil matrix of each pit, as well as to differentiate adjacent spaces. Schematically, two zones devoid of ceramic and stone material have been identified on both sides of two oblong piles (Figure 2d). To the west of these intermediate spaces, in the space defined by one of the piles (east), a short ridge (west), and a terrace (south), two test pits and one trench dug into this terrace revealed the presence of a vast depression characterized by a deep clay soil $60-80 \mathrm{~cm}$ thick, with ceramic sherds present, but no stones. This clay zone extends $20 \mathrm{~m}$ to the north toward the neighboring dwelling. To the north of the latter, another clay zone has been identified and tested: the large, rectangular space bounded by a quarry to the north, terraces to the east and ridges to the south and west, apparently lacks any construction, yet it provided a small amount of cultural materials. Thus, analyses strongly suggest that some clayed soils resulted from an anthropic contribution of clay probably extracted from local swamps and aguadas, contemporary with the occupation. In other soils, stones have been removed, and still others seem to have been intentionally improved by domestic waste spreading, as indicated by the presence of small quantities of ceramic sherds.

\section{DISCUSSION}

Let us now switch from the description of individual structures to the analysis of the overall system, to see if we can understand how the space was organized, and to reconstruct some guidelines in the construction of the landscape as revealed through these investigations. Can we retrieve the point of view of the builders themselves (Guilaine 1991)? How did the structures relate to one another, what roles did they play on the landscape, and how did the residents modify it? Here, we tackle the key issue of how the local environment was anthropized, so as to reconstruct an image of the Late Classic period landscape (Kanlol [A.D. 550-700] and Makan [A.D. 700-850] phases). As shown, except for the circular piles of stones, most of the components date to that period.

\section{Houses and Possible Agricultural Features within the Landscape: An Agrarian System?}

The highly contrasted environment of the Río Bec nuclear zone is divided by large low-lying wet sectors. Neither modified nor occupied (with the exception of large aguadas), the swamps form obvious basic boundaries within the network of dwellings (Figure 3). The latter were built on elevated zones (the five interfluves within the 50 ha studied), which dominate flooded land and are characterized by well-drained soils. On these interfluves, soils were modified, managed and some of them even improved. One or more elite residences systematically occupied the higher parts of the interfluves and, at a lower level, the slopes were terraced to preserve soils from erosion. The gentlest slopes show densely packed structures, including residences of all ranks and features such as reservoirs, quarries, agricultural terraces, ridges, and stone piles. It should be noted that, at least in our research zones, there are no concentrations of dwelling units, as all of them are scattered and separated from one another by what appear to be land 

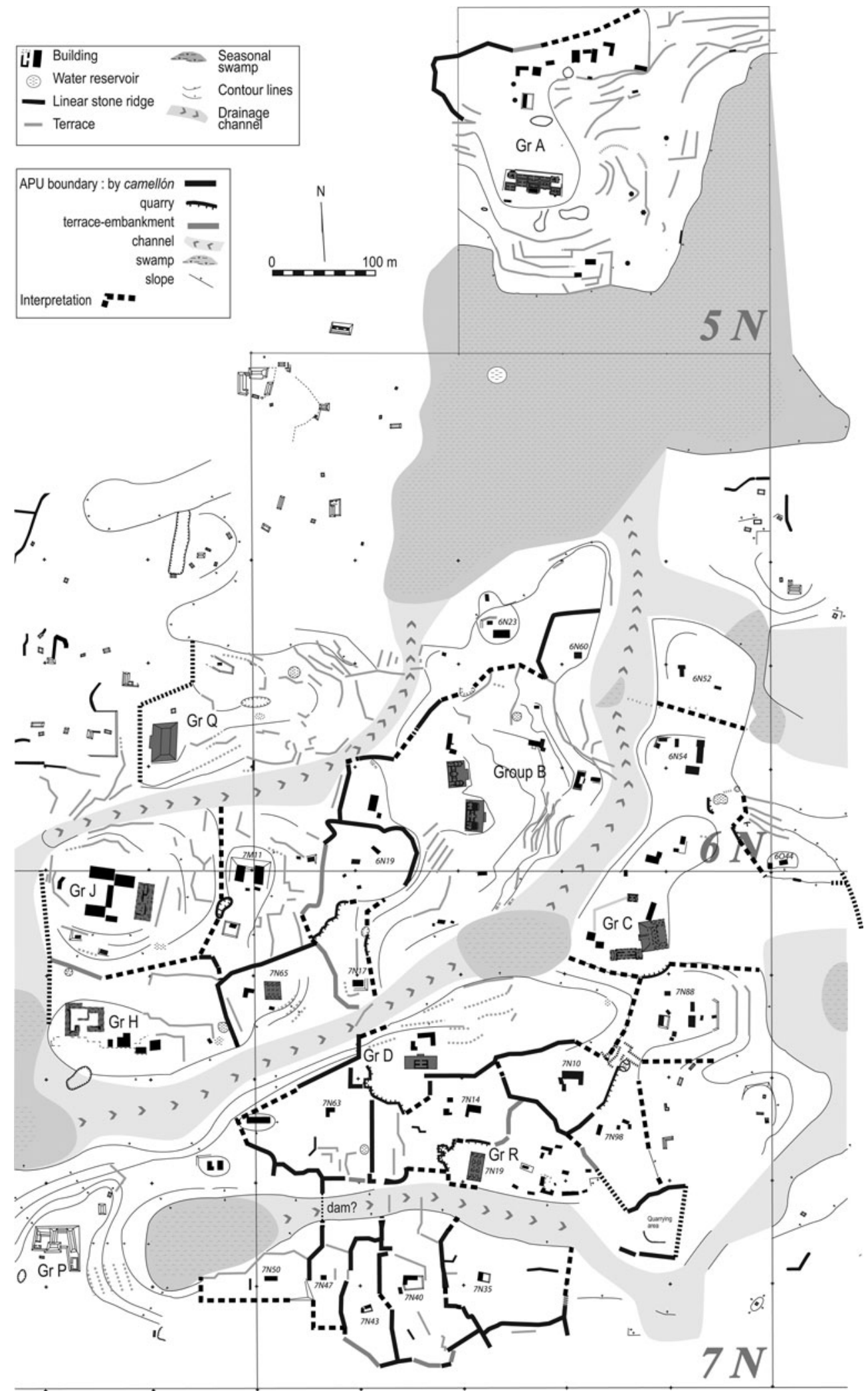

Figure 8. Delimitation of agrarian production units (APU), or "farmsteads", within the 8 ha zone, the 33 ha zone, and 9 ha around Group A (S.P. VIII-IA-2005-2008), Río Bec nuclear zone. Drawing by Eva Lemonnier. 
management features. In these areas-leveled, terraced, or gently sloping - the data obtained from intermediate spaces test pits show that the soils are diversified and many have certainly been modified, perhaps to adapt to specific crops.

Specific associations between soil content, geomorphologic characteristics, dwellings, and land features can be found. The terraces best illustrate this and, as the most common form of land modification at Río Bec, they make up still-visible vast networks on the modern landscape (Figures 3 and 8). Their spatial association with elite residences is remarkable, particularly for those houses built on prominences with slopes suitable for terracing. Long, high, and contour-hugging, these terraces are similar to those described by B.L. Turner II (1983) who first discovered them in the region. They are classified as "contour terraces," the most common type in the Maya area (Dunning 1993; Dunning et al. 1993; Fedick 1994). A few contain perpendicular sections that may be evidence for "box terraces" (Dunning and Beach 1994). A few others located at the foot of steep slopes may represent a third type known as "foot-slope terraces," first defined in the Petexbatun region of Guatemala, that are designed to catch colluvial sediments (Dunning and Beach 1994).

Not far from the dwellings are also found quarries. They are often only a few meters away and, at times, at the foot of the buildings (or even beneath them, as in Groups Q or 7N19) from where stone material was extracted, so that it is easy to ascribe each to its HU. The quarries were opened and the large houses were built where they would allow builders to save work time. But the correlation of large quarries with large houses is imperfect, and the disproportion between certain quarries and the nearest small houses is problematic. This issue is worthy of more systematic research in the future. Certain disproportionate instances might be explained by local long ridges made of enormous quantities of stone obtained from quarries, rather than by removing stones from plots. It is surprising, nonetheless, that vast quarries should have reduced the cultivable spaces. Even if the inhabitants of Río Bec emphasized constructing large houses while managing their cultivated land, the surface given over to quarries is perplexing. It must be noted that in several cases large cutting fronts hinder the most direct access between two neighboring HUs, suggesting that like the ridges, the quarries likely served as frontiers between units. Otherwise, preliminary evidence from one quarry suggests that in some cases at least soil may have been brought in and cultivated (Gillot 2010:9-10).

The ridges are characterized by their length (up to $50 \mathrm{~m}$ in our research zones), their occasionally cardinal orientation, often perpendicular arrangement to the main drainage orientation, and their location in relatively flat spaces less than $30 \mathrm{~m}$ away from dwellings (Figures 3 and 8). They are the features that structure the landscape most, as they often divide a sub-horizontal space shared by several small HUs (see below). In this way they created new axes organizing the landscape, forming a notable spatial division. But some of them also created plot-type compartments with differing soil characteristics. They may therefore be interpreted as long, rectilinear, relatively high boundaries, often at right angles to one another. Some shorter, narrower $(1-1.5 \mathrm{~m})$ and lower $(50-60 \mathrm{~cm})$ ridges subdivide the interior of compartments. Thus, besides demarcating plots probably used for different agricultural purposes, small ridges appear to have contributed to control rainwater runoff by modifying the natural relief. They do not show evidence of multistage construction.

Morphologically, the Río Bec ridges can be compared to those of Becan (Thomas 1981:12-13, 87-88) and to the "berms" of La
Milpa (Kunen 2001:335, 339). At both sites they are described as linear rubble (or cobble) features with a crude basal retaining wall, varying in length from 3 to $50 \mathrm{~m}$ in the Far West Bajo (La Milpa), to $150 \mathrm{~m}$ at Becan where they can reach $2 \mathrm{~m}$ in height and $5 \mathrm{~m}$ in width. Like the Río Bec ridges, those of Becan would have been constructed during the Late Classic period (Bejuco phase; A.D. 600-700). Functionally, the Far West Bajo berms, located in a zone of agricultural production distant from residential areas, are interpreted as water control features (see also Chase and Chase [1998] at Caracol and Fedick et al. [2000] in Yalahau region) in association with a terracing system. At Becan (Thomas 1981:88, 94, 106), besides directing runoff, some ridges may have been used as terraces, raised walkways, or property boundaries (for discussion of field walls and terracing in northwestern Belize, see also Beach et al. [2002]; Hughbanks [1998]; Tourtellot et al. [2003]). Clearly differentiated from these ridges, numerous boundary walls define house lots encircling residential structures and perhaps delineating household garden plots (Thomas 1981:87, 106). These walls, dated to the Terminal Classic period (Xcocom phase), are compared to those of Mayapan; that is, the low dry stonewalls (less than $1 \mathrm{~m}$ in height) commonly referred as albarradas at northern Maya sites. They are single- or double-faced walls, composed of unworked or roughly shaped slabs and stones of all sizes — with or without rubble or pebble fill—and they outline and enclose household compounds (Folan et al. 1983:94-101). As they constitute a continuous and contiguous network and outline the households, they usually show a "honeycomb-like configuration" (Hutson et al. 2004:81). In spatial layout and morphology (dimensions and construction methods), the boundary walls or albarradas apparently do not exist at Río Bec where the local ridges are distinct. It is possible that albarradas enclose smaller surfaces (less than $2500 \mathrm{~m}^{2}$ ), that are functionally often compared to the modern solar (house lot), and are generally interpreted as social boundary markers (Hutson et al. 2004:81), and/or garden plot delimitations (Ball and Kelsay 1992; Folan et al. 1983; Killion et al. 1989; Manzanilla and Barba 1990; Smyth et al. 1995). The latter function would make them equivalent to the Río Bec ridges, also associated with systems of terraces and stone piles like those at Becan, La Milpa, and elsewhere. Details in morphology and spatial structure require further comparative study on the ground.

The spatial association of the oblong-shaped stone piles appears strongest with aguadas, with some plots where soils have low stone content, and with quarries. As mentioned, the pile composition in layers reflects a rather continuous, progressive construction process. These features may well have resulted from stone-removal practices carried out in some fields and other places, simultaneously providing reserves of construction material used in fill for residences and terraces. Both functions are compatible since the reserves are contemporary with the most intense construction period at Río Bec (during the Kanlol and Makan phases). Moreover, when they cover earlier occupational remains, the stone piles may consist of materials collected from ruins, effectively clearing their surroundings. This does not, however, rule out their having been used to demarcate spaces for distinct purposes.

Aguadas might be expected to be numerous, scattered, and closely related to the HUs (see Weiss and Sabbas 2002). As a matter of fact, they are few in number (11 of 40 HUs in zones 8 and 33) and small in size (five are $10-15 \mathrm{~m}$ in diameter and six others range from 4.5 to $9 \mathrm{~m}$ in diameter). Other forms of water supply have to be considered, beginning with adjacent marshes. 
Five small subterranean chambers of apparent chultun morphology were found in the nuclear zone (159 ha), yet they were certainly used to extract sascab (limestone sand) (Nondédéo 2002:55) rather than hold rainwater. In the case of the large aguadas, some were probably shared by several social groups, which may imply some degree of solidarity among them. Located on the edge of a bajo, the largest aguada (El Tintal, at $40 \mathrm{~m}$ in diameter) (Figure 1) was certainly shared between several units, including the nearest monumental Groups B, C, and O.

Pertaining to what may be called "water control," all reservoir types raise the issue of rainwater drainage. At least two elements suggest there was actually a fairly complex management of rainwater. First, certain ridges prevented natural runoff by limiting flood speed from the talweg slopes, in particular. They may be evidence of former dam-type constructions (probably made partly of perishable material) that held back part of the precipitation above the lower-lying land (Figure 8). Second, the compartments created by ridges (among other features) protected some spaces from flooding by promoting drainage and dividing the water flow by sectors; for example, by evacuating and redirecting the runoff through purposely made openings.

With the circular-shaped stone piles, we move slightly backward in time from the Late Classic system discussed above. At Río Bec they are earlier than the other structure types, many of them are found in clusters, and the excavated piles do not cover earlier remains. They compare well to the small mounds at Becan (Thomas 1981:79-86), to the "rockpiles" at La Milpa (Kunen 2001:333), and more generally to the chich mounds reported in northern Yucatan and Belize. The function of this structure type is still unclear, but several interpretations have been deduced from their dimensions, composition, and location: remains of outbuildings, storage structures, field houses, stockpile (reserves of fill material and chert), dumps, and middens (Thomas 1981:107; Kunen 2001:333). Some scholars have proposed they reflect activities such as clearing fields (Killion et al. 1989:285-286; Thomas 1981:107) or arboriculture as practiced in modern Yucatan, considering that gravel piles conserve moisture and allow trees or other crops to grow in shallow soils (Kepecs and Boucher 1996:76; Pyburn 1998). Their distinct locations within whole settlements strengthen the hypothesis that chich mounds could have served several purposes (Killion et al. 1989: 286; Kunen 2001:337, 342). That they also may be the remains of small dwellings is not excluded at Becan, Sayil, and also Komchen (Ringle and Andrews 1988: 179-186). At Río Bec, their early dating is probably the best argument, along with morphology, organization in small clusters and associated archaeological material (a few lithic tools, in particular), to hypothesize that these piles are the vestiges of early platforms. Few chronological data are generally available for chich mounds; at Becan they date from the Sabucan and Bejuco phases (the site apogee). At Río Bec, the 10 tested piles precede the apogee, and none yielded Makan phase sherds. They are thus interpreted as small stone-filled platforms having sustained perishable dwellings or ancillary constructions built before A.D. 550 (Iximche phase; at the latest between A.D. 550 and 700 [the Kanlol phase]), abandoned just before Río Bec's apogee, and then altered by stone removal during the apogee. These ruins were still visible in the Late-Terminal Classic landscape. In an agrarian context, they may have had a symbolic function connected to the ancestors, that is, in some way they may have marked property bounds (Vapnarsky and Le Guen 2011).

Accepting the previous interpretation, it can be concluded that all categories of structures here analyzed are interrelated in a way that makes probable they had an agricultural function. Protection against soil erosion, soil modification, and management of rainwater runoff altogether signal systematic use of the local environment for crop production. It is reasonable to argue that all the components of this anthropized landscape were part of a genuine agrarian system. On the basis of analyzed relations, the system's main features should now be outlined and interpreted to deduce a model of resource use for Río Bec in the Late-Terminal Classic period.

\section{Farmsteads and Homesteads: A Model of Socio-Economic Organization}

Besides the required work intensification and the implied complex recycling of materials, there is no doubt that the most striking characteristic in this anthropized landscape is the diversity of modifications and techniques applied. Also noteworthy is the fact that the features, though crudely built, seem to have been quite effective, at least insofar as they are still well preserved. A third characteristic is that the spaces seem highly compartmentalized, with very small plots serving as farming units (Figures 3 and 8). At the scale of the Zoom Zone, the study of the archaeological distribution of remains allows us to distinguish between inhabited spaces (abundant ceramics), cultivated spaces (very few ceramics), and even circulation spaces (the absence of ceramics). Moreover, soil studies have drawn a distinction between plots where stones have been taken out, depressions with clayey soils, and plots with improved soils. Divisions between small fields are marked horizontally by features of the linear stone-ridge type, and vertically by terraces moreover accentuated by natural topography. In the Zoom Zone, our refined analysis revealed units varying from 500 to $1000 \mathrm{~m}^{2}$. Instead of loci for differentiated craft activities (except the quarries, which are such loci), morphology and context rather qualify the spatial partition as an agrarian system comprising plots or fields with specialized agricultural uses, complementary with one another and intensively cultivated. In addition to partitioned spaces with diversified soils, the system also encompasses specific features separating circulation and occupation, controlling natural drainage, creating flat cultivable surfaces, preventing soil erosion, and building physical, visible boundaries. The north-south orientation of the largest linear features even evokes a standardized agricultural field system (see Guy [1987], for discussion of the Mexican central highlands). Although it deserves further research, a constructed field system encircling the houses may have characterized the Río Bec agrarian system.

Within the system, houses are found dispersed over the interfluves. To understand how they actually fit in, a specific spatial analysis was carried out to define their relationship with the land use features. Instead of specialized spaces with only one or two agricultural features connected to several HUs, each HU is spatially associated with several feature types, as if inhabitants discarded interdependency among neighbors in subsistence and residential construction needs. Some features, particularly the ridges, even segregated one HU from its nearest neighbors. Consequently, our hypothesis is that each $\mathrm{HU}$ and the surrounding field system formed an agricultural production unit (APU) that must be considered as distinct and autonomous from its neighborsalthough, this does not mean that every APU had reached complete self-subsistence capacity (Figure 8). "Farmstead" is a concept-first introduced by Eaton (1975) for the Río Bec region-that keeps being expanded and supported by data from both urban and rural areas over the Maya lowlands (Dunning 2004). 
Table 2. Characteristics of the 26 Agricultural Production Units (APU) defined within work Zones 8 and 33, with the addition of Group A. Each APU normally includes only one Household Unit (HU), but some include more than one ${ }^{2}$

\begin{tabular}{|c|c|c|c|c|c|c|c|c|c|}
\hline \multirow[b]{2}{*}{ Interfluve identification } & \multirow[b]{2}{*}{ APU code } & \multirow[b]{2}{*}{ No. of $\mathrm{HU}$} & \multirow[b]{2}{*}{ HU rank } & \multicolumn{3}{|c|}{ Limits } & \multirow[b]{2}{*}{ No. of Terraces } & \multirow[b]{2}{*}{ No. of stone piles-ruins } & \multirow[b]{2}{*}{ APU area (ha) } \\
\hline & & & & Ridge & Quarry & Relief & & & \\
\hline South & $7 \mathrm{~N} 47$ & 1 & late & $\mathrm{x}$ & & $\mathrm{x}$ & 3 & 3 & .35 \\
\hline \multirow[t]{2}{*}{ Gr B } & $7 \mathrm{~N} 17$ & 1 & late & & $\mathrm{x}$ & $\mathrm{x}$ & $2^{*}$ & 0 & .35 \\
\hline & 6N60 & 1 & VI & $\mathrm{x}$ & & $\mathrm{x}$ & 0 & 2 & .25 \\
\hline \multirow[t]{2}{*}{ South } & $7 \mathrm{~N} 43$ & 1 & VI & $\mathrm{x}$ & & $\mathrm{x}$ & 0 & 3 & .4 \\
\hline & $7 \mathrm{~N} 50$ & 1 & $\mathbf{V}$ & $\mathrm{x}$ & & $\mathrm{x}$ & 1 & 10 & .45 \\
\hline \multirow[t]{2}{*}{ Gr C \& D } & $7 \mathrm{~N} 10$ & 1 & $\mathbf{V}$ & $\mathrm{x}$ & $\mathrm{x}$ & $\mathrm{x}$ & $?$ & $?$ & .6 \\
\hline & 6044 & 1 & $\mathbf{V}$ & $\mathrm{x}$ & $\mathrm{x}$ & $\mathrm{x}$ & 4 & $?$ & .65 \\
\hline \multirow[t]{2}{*}{ Gr B } & 7N98 & 1 & $\mathbf{V}$ & $\mathrm{x}$ & $\mathrm{x}$ & $\mathrm{x}$ & $1 *$ & $?$ & .65 \\
\hline & $6 \mathrm{~N} 19$ & 1 & $\mathbf{V}$ & $\mathrm{x}$ & $\mathrm{x}$ & $\mathrm{x}$ & 0 & 6 & .65 \\
\hline Gr C \& D & $6 \mathrm{~N} 52$ & 1 & $\mathbf{V}$ & & & $\mathrm{x}$ & 0 & 1 & .75 \\
\hline \multirow[t]{2}{*}{ South } & $7 \mathrm{~N} 40$ & 1 & $\mathbf{V}$ & $\mathrm{x}$ & & $\mathrm{x}$ & 6 & 10 & .9 \\
\hline & $7 \mathrm{~N} 35$ & 1 & $\mathbf{V}$ & $\mathrm{x}$ & & $\mathrm{x}$ & 1 & 2 & .9 \\
\hline Gr B & 7 N65 & 1 & $\mathbf{V}$ & $\mathrm{x}$ & & $\mathrm{x}$ & $2^{*}$ & 0 & .9 \\
\hline \multirow[t]{2}{*}{ Gr C \& D } & $7 \mathrm{~N} 63$ & 1 & $\mathbf{V}$ & $\mathrm{x}$ & $\mathrm{x}$ & $\mathrm{x}$ & 5 & 5 & .9 \\
\hline & $7 \mathrm{~N} 14$ & 1 & $\mathbf{V}$ & $\mathrm{x}$ & $\mathrm{x}$ & $\mathrm{x}$ & 4 & 1 & .95 \\
\hline Gr B & $6 \mathrm{~N} 23$ & 1 & V & $\mathrm{x}$ & & $\mathrm{x}$ & $6^{*}$ & 3 & 1.2 \\
\hline Gr C \& D & $7 \mathrm{~N} 88$ & 1 & IV & & $\mathrm{x}$ & $\mathrm{x}$ & 2 & $?$ & 1.1 \\
\hline Gr B & 7M11 & 3 & IV & $\mathrm{x}$ & $\mathrm{x}$ & $\mathrm{x}$ & $10^{*}$ & 0 & 1.5 \\
\hline Gr C \& D & 7N19 & 1 & III & $\mathrm{x}$ & $\mathrm{x}$ & $\mathrm{x}$ & $?$ & $?$ & $1.3 \mathrm{~min}$ \\
\hline Gr C \& D & Gr D & 1 & III & $\mathrm{x}$ & $\mathrm{x}$ & $\mathrm{x}$ & $3^{*}$ & 4 & 2 \\
\hline Gr Q & Gr Q & 2 & III & $?$ & $?$ & $\mathrm{x}$ & $28 *$ & 1 & $2.5 \mathrm{~min}$ \\
\hline \multirow[t]{2}{*}{ Gr B } & $\mathrm{Gr} \mathrm{H}$ & 2 & II & $\mathrm{x}$ & & $\mathrm{x}$ & $3^{*}$ & 0 & $1.9 \mathrm{~min}$ \\
\hline & Gr J & 2 & II & $\mathrm{x}$ & $\mathrm{x}$ & $\mathrm{x}$ & $14 *$ & 2 & $2.25 \mathrm{~min}$ \\
\hline Gr C \& D & $\mathrm{GrC}$ & 2 & I & $\mathrm{x}$ & $\mathrm{x}$ & $\mathrm{x}$ & $?$ & $1^{*}$ & $3.5 \mathrm{~min}$ \\
\hline Gr A & Gr A & 4 & I & $\mathrm{x}$ & & $\mathrm{x}$ & 43 & 6 & 3.5 \\
\hline Gr B & Gr B & 4 & I & $\mathrm{x}$ & $\mathrm{x}$ & $\mathrm{x}$ & 20 & 4 & 4.5 \\
\hline TOTAL & 26 & 38 & / & / & / & / & 158 & 64 & 34.9 \\
\hline
\end{tabular}

${ }^{2} \mathrm{x}=$ presence;

$*=$ the actual quantity of terraces may be higher;

Ranks I-III correspond to monumental residences in architecture;

Ranks IV-V correspond to medium or intermediate residences;

Rank VI to common housing (no vaulted building).

Note: this ranking is valid for Makan 2-Xpuhuk 1 subphases and was established independently from the present analysis (see Nondédéo et al. 2013);

Early dwelling units are not included;

"Late" = unit founded later in Xpuhuk phase.

The APU pattern of socioeconomic organization that we propose for Río Bec is valid for the second half of the Late Classic (Makan phase; A.D. 700-850) and at least the beginning of the Terminal Classic (Xpuhuk 1 phase; A.D. 850-900), periods of intensive construction for both residences and agricultural management. The .5 ha Zoom Zone provided the basis for formulating the pattern of spatial organization, subsequently validated in Zones 8 and 33 (41 ha) and the 9 ha around Group A. This pattern is defined as follows: (1) each APU includes a single HU; (2) it is circumscribed by linear ridges, quarries, and/or sharp slope breaks in the natural topography, sometimes marked by an artificial embankment; (3) it is internally structured by means of varied land management facilities, terraces, oblong piles of stones, short ridges, aguadas, creating compartments in which various techniques were applied to make use of local soil resources, while certain features modify ruins of abandoned dwellings; and, (4) because of runoff and erosion control requirements, each network of terraces is under the control of the nearest HU located above them, rather than below.

Implementing this pattern as a model, we were able to define 26 APUs in the 50 ha studied (Figure 8 and Table 2). For 19 of them
(73\%), assigning each APU to one particular HU presented no difficulty. For the remaining seven, the rule of one APU for one HU does not seem to work, and "sharing" between two to four households has to be considered. These are the largest APUs, associated with the most monumental edifices (Groups A, B, C, J, H, Q, and $7 \mathrm{M} 11$ ), that dominate the topography, each overhanging a network of terraces on which is located one HU of inferior rank, rarely more than one. According to the chrono-ceramic dating of the Groups A, B, and D neighboring units (Nondédéo et al. 2013; Taladoire et al. 2013), some of the low-rank units were abandoned in either the Kanlol or the Makan phase, which partially explains the large dimensions of the APUs in which they are found, their lands having been probably appropriated by the members of the monumental unit. But other small neighboring HUs maintained their existence, seemingly cooperating with the higher-ranking social group (for example, two units east of the Group B largest residences, and 5N15 north to Group A) (see Figure 8). It remains that most of the APUs include one single HU.

Comparing the APUs, it is striking to see that the Group B production unit seems to have been the most powerful at the scale of our 
larger work zone, in view of the agricultural surface that it can be assigned. Group A has twice as many terraces as Group B, and Group $\mathrm{C}$ may have had the advantage of good cultivable wetlands on the edge of the eastern swamp (see below). Interestingly, Group $\mathrm{C}$ is an exception in having no terraces, whereas monumental houses can be seen to dominate vast series of terraces (comparable to the "feudal manor houses" discussed by Adams and Smith [1981]), but this may be due to its chronological placement. In contrast, the lesser household units are systematically associated with long ridges surrounding them (instead of terraces) in generally flat spaces where the natural topography makes it difficult to differentiate between neighboring farmsteads. Built physical boundaries certainly would have helped avoid disputes. In other words, it can be said that there was a certain tendency for the lesser HUs to protect themselves from the larger HUs, and for the latter to invest in terracing slopes.

Although the talwegs and their banks were not fully investigated (with only three test pits), the presence of a possible dam and some ridges extending down to the bajo edges (Figure 8; south swamp) suggests that local wetlands were probably used and managed. The ancient use of wetlands for agriculture is well documented for different parts of the Maya lowlands and for all periods (including modern times: see Culbert et al. 1990, 1997; Dunning et al. 2002; Fedick et al. 2000; Kunen 2004; Pohl 1990; Wilk 1985). At the very least, the Río Bec swamps probably provided water during part of the year and continuous moisture on edges during the dry season.

All works undertaken by the Classic Maya at Río Bec evidence not only a remarkable adaptation to the environment, but also- and above all-a genuine landscape construction. Members of both small and large dwelling units obviously mastered specific techniques and had efficient know-how. Time and energy were invested in demarcating parcels of land and managing them to improve agricultural production. These observations tend to confirm the premise of HU autonomy on which our model is based. The quarries do not appear to have been shared either. The clearly defined boundaries suggest that social groups of the higher-ranking units did not control their lower-ranking neighbors, except in the cases mentioned where the latter were located on terraces networks around Groups A and B (see above). The residential and productive units had a rather high degree of autonomy, although spatial and chronological analyses point to a few cases in which adjacent social groups were absorbed by larger ones, or expelled.

Some household units developed a domestic architecture far superior to that of the majority, but on the economic level, the lower- and middle-ranking farmsteads are perhaps the most interesting. The way that each APU is divided and its land carefully structured indicates that all the work needed for land management and agricultural production could only be done at the scale of the individual household. The small APUs average .5 ha (from a quarter to one full hectare), a variation coinciding quite well with the intrasettlement fields measured in Classic Maya sites even more urban than Río Bec (Lemonnier 2009:85-86). In such an infield type of agriculture developed next to the dwelling facilities productivity could be very high (Netting 1977). But, no data allows us to calculate to what extent the local population was able to subsist on such production units. "Landscaping" appears to have been sufficiently elaborate to safely say that local producers invested a great deal in infield agriculture precisely because it was an important source for their subsistence, or because it was their only source.
The lowest-ranked dwelling units (Rank VI, without vaulted building) have APUs covering less than .5 ha (Table 2). The intermediate units (Ranks V-IV, with at least one vaulted building) have APUs between about .5 and 1.5 ha. The monumental units have APUs larger than 1.5 ha-reaching up to 4.5 ha in Rank I. Except for one case where the area of the APU seems too large for the associated household unit $(6 \mathrm{~N} 23)$, the ranking of all defined APUs by surfaces correlates remarkably well with the ranking by architecture of the corresponding HU obtained by Arnauld in an analysis conducted independently from ours (Nondédéo et al. 2013). It shows a continuum of APU areas from Ranks VI up to II (.25-2.5 ha). On the other hand, from Rank II to Rank I there is a break insofar as the APU areas nearly double (from 2-4 ha). So an APU's area depends on the rank of its household unit; the Rank I APUs clearly stand out, being twice as large as the rank immediately below. The coherent hierarchy in farmstead productive surface area and residential architectural elaboration provides a relevant argument to suggest that differences in agricultural production made possible the socioeconomic distinctions reflected in residential architecture.

All this begs the fundamental question of what types of crops allowed the suggested socioeconomic differentiation, beyond maize, bean, and squash staples. Our attempts to recover phytoliths, seeds, and other types of macroscopic remains within soils and dwellings were unsuccessful (although carbonized and noncarbonized plant remains were obtained from funerary and culinary contexts, currently under analysis). There is no reason to discard the evidence given by the north façade iconography of the large residence (Group A) 5N2, where cacao plants bearing large fruits seem to be represented (Michelet et al. 2013).

\section{CONCLUSION}

Through a multidisciplinary and multiscalar approach applied to nearly a third of the Río Bec nuclear zone (50 of 159 ha), it has been possible to forward a reasonably precise model of agrarian organization. On three different spatial scales-.53, 8, and 50 ha-archaeological techniques have been combined in association with microtopographic survey. As a pioneering method of cartography in the Maya area where the forest environment is a strong limiting factor, this type of survey allows for the reconstruction of human settlement effectively, reliably, and quickly in its local context, optimizing pedestrian reconnaissance. Besides locating the smallest mounds in the Río Bec archaeological sample (circular stone piles, barely visible on the surface), the microtopographic surveys revealed many rectilinear structures (ridges). These are interpreted as fundamental components of an agrarian pattern characterized by a (pseudo-) standardized field system encompassing houses. This field system is the first of its kind to have been so precisely mapped in the Maya area.

Developed after A.D. 600 by Río Bec farmers, the built field system helped maintain relatively autonomous agrarian units (APUs). Each unit corresponds to a "domain" delimited by mostly visible boundaries like built ridges, open quarries, and natural topographic ruptures. The domain was modified and structured by means of numerous and varied kinds of land management features that shaped the landscape providing new organizing axes. Only one household unit is associated with each domain. The cases of multiple households on one domain are rare and only concern some monumental units where such occurrence can be interpreted in the sense of a relation of subordination. 
Considering all analyzed APUs, the relations between construction and crop-growing activities are reflected in a significant correlation between the household unit rank defined by its degree of architectural monumentality, and the surface area of the corresponding APU. Although less easily quantified, positive correlations also exist between higher-rank households and large terrace networks on the one hand, and lesser-rank units with encircling ridges on the other. Both are sufficiently clear to suggest that some large units, while intensifying their production mode with terracing, were expanding and threatening small units. As for the ultimate cause of the differentiating process, the functional diversity and complexity of all structures in one domain rather suggest that both processes, architectural elaboration and agricultural intensification, developed simultaneously following intricate dynamics. The Río Bec settlement provides us with the image of a society that was in the process of being formed, instead of an achieved society. The archaeological record reflects its dynamics, even perhaps to the degree that disputes on field or domain limits can be suspected in some locales. In our introduction, we suggested that the Río Bec settlement differs from contemporary Maya cities due to weak nucleation trends. An in-depth study comparing its agrarian system with that of cities having agricultural vestiges more or less visible on surface, such as networks of field walls, would perhaps nuance the contrast. It is relevant to emphasize that, given the continuous residential remains blanketing the entire region, the existence of outfield agriculture would be difficult to assess for Classic period times, a fact that entails that the Río Bec infield system may well have produced most of the staple crops needed for the subsistence of local population. Río Bec agricultural production units, even of small size (ranging from .25 ha up to more than 4.5 ha), were not just kitchen gardens, but farmsteads combining specific plots and fields, possibly kitchen gardens and/or orchards, as well as fields producing staple crops.

Setting aside the apparent dichotomy of garden-groves versus subsistence fields applied to Maya intrasettlement agriculture (Lemonnier 2009:83-87), or "garden city" (Tourtellot et al. 1988) versus "agrarian city" (Arnauld 2008; Arnauld and Michelet 2004), we argue that the case of Río Bec contributes to the study of agriculture in Classic Maya societies by bringing complexity, displaying the technical intricacies of a social and agrarian process over at least three centuries (from A.D. 600 to 900). Judging by the number, extent, and functions of the modifications brought to the landscape at Río Bec, the agrarian system was intensive and viable over the relative long term. It allowed the development of a society that, although maintaining its rural traits, produced buildings among the most prestigious in the Maya area. The fact that the collapse of this society did not occur much later than that of the great contemporary cities suggests the deepest causes were of a sociopolitical and/or climatic nature rather than directly linked to agricultural intensification.

\section{RESUMEN}

La "zona nuclear" de Río Bec (159 ha) muestra un patrón de asentamiento de tipo rural, con viviendas dispersas y espacios intermedios ocupados por numerosos y diversos acondicionamientos de supuesta función agrícola. Se diferencia también de muchos otros sitios mayas contemporáneos por la ausencia de un centro político-religioso. Su densidad residencial es de 2.1 estructuras por hectárea $\left(209 / \mathrm{km}^{2}\right)$, una densidad baja, si se compara con la variación observada entre sitios mayas del clásico tardío (150-400 estructuras $/ \mathrm{km}^{2}$ ). Las viviendas tienen morfologías bastante distintas: varían desde modestas casas construidas con materiales perecederos hasta residencias monumentales en el estilo arquitectural denominado Río Bec, lo que probablemente refleja una fuerte jerarquía social dentro del asentamiento. Entre los acondicionamientos agrarios, pudimos observar terrazas semejantes a las que fueron reconocidas en la región en los años 1970 por B. L. Turner; se trata de hipotéticas cercas de piedras llamadas "camellones" (también descritas por Carrasco Vargas y otros investigadores), así como canteras y aguadas, que constituyen los rasgos más comunes en el área maya.

La constitución interna de Río Bec nos llevó a plantear a modo de hipótesis la existencia un sistema agrario local basado en una agricultura intensiva en torno a las viviendas, que pudo haber determinado la orgnanización del asentamiento. En el marco de esta investigación multidisciplinaria, hemos empleado varios acercamientos metodológicos y empleado distintas escalas; por ejemplo, levantamientos micro-topográficos, sondeos pedológicos, excavaciones arqueológicas y reconocimientos de superficie. La zona de estudio comprendía unas 50 hectáreas en total; nuestro trabajo consistió en reconstruir una imagen de la antropización del paisaje durante el auge de la sociedad Río Bec en el clásico tardío (fase Makan, 700-850 d.C.). Al caracterizar las estructuras, los espacios y los suelos, a la par que se identificamos formas de aprovechamiento agrícola intensivas y evaluamos el grado de transformación y/o acondicionamiento del paisaje, logramos construir un modelo de organización espacial y de aprovechamiento de los recursos. Un elemento integral de este modelo fue el uso de la noción de "parcelario," el diseño general de parcelas de cultivo, en el que se enmarcaron las unidades residenciales de la zona de estudio.

El parcelario muestra un alto grado de compartimentalización; es decir, pequeñas parcelas fueron creadas por rasgos lineales ("camellones"), varios de ellos con orientación cardinal. Las parcelas vecinas estaban espacial y topográficamente relacionadas con ciertas unidades habitacionales. Así, la reconstrucción del parcelario de Río Bec y las viviendas asociadas, constituye el primer ejemplo de un caso de este tipo interpretado y cartografiado en las tierras bajas mayas. Esto ha llevado a la precisa definición de las diferentes unidades de producción agrícolas (UPA). Cada UPA se compone de una sola unidad habitacional, asociada con cierta extensión de tierra y delimitada por camellones, canteras y/o rupturas de pendiente marcadas, modificada y estructuradas en parcelas. Estas unidades habrían cumplido fines residenciales y agrícolas por medio de varios tipos de acondicionamientos, en particular terrazas y camellones.

La división del territorio y las modalidades de su aprovechamiento sugieren que cada unidad habitacional gestionaba la producción agrícola de modo autónomo. Del mismo modo, no hay ninguna evidencia generalizada de que grupos sociales de un estatus superior hayan controlado la producción. Aunque todavía falta evaluar el grado de auto-subsistencia de cada unidad mediante índices de producción agrícola y de carga demográfica, al comparar las 26 UPA definidas adentro de los 50 ha estudiados se observa una fuerte correlación entre el tamaño y rango jerárquico de las unidades habitacionales por un lado, y las superficies de las UPA correspondientes por el otro. Dicha correlación proporciona un argumento relevante para sugerir que diferencias en producciones agrícolas pudieron determinar capacidades socio-económicas relevantes en cuanto a inversión en arquitectura más o menos monumental. El presente estudio contribuye a las investigaciones dedicadas a la relación hombre/medio ambiente en las tierras bajas mayas clásicas, esclareciendo los complejos procesos sociales y agrarios que operaban en dichas sociedades. 


\section{ACKNOWLEDGMENTS}

We would like to thank the directors of the Río Bec Project, Dominique Michelet and M. Charlotte Arnauld, who supported our program with attention and enthusiasm. We owe our deepest gratitude to George Marchand and Agnès Stock for valuable microtopographical data, a key component of our study, and to Sara Dzul for precise chrono-ceramic expertise. The helpful comments provided by all members of the project have been much appreciated, with special thanks to Laure

\section{REFERENCES}

Adams, Richard E.W.

1981 Settlement Patterns of the Central Yucatan and Southern Campeche Regions. In Lowland Maya Settlement Patterns, edited by Wendy Ashmore, pp. 211-257. University of New Mexico Press, Albuquerque.

Adams, Richard E.W., and Richard C. Jones

1981 Spatial Patterns and Regional Growth among Classic Maya Cities. American Antiquity 48:301-322.

Adams, Richard E.W., and Woodruff D. Smith

1981 Feudal Models for Classic Maya Civilization. In Lowland Maya Settlement Patterns, edited by Wendy Ashmore, pp. 335-349. University of New Mexico Press, Albuquerque.

Andrieu, Chloé

2008 Informe de la lítica, Temporada 2007. In Proyecto Río Bec (Campeche México). Informe de la sexta temporada de campo, del 4 de febrero al 3 de mayo de 2007, edited by Dominique Michelet. Instituto Nacional de Antropología e Historia-Centro de Estudios Mexicanos y Centroamericanos. Report on file, Instituto Nacional de Antropología e Historia, Mexico City.

2009 Outils mayas: Distribution et production du silex et de l'obsidienne dans les Basses Terres. Ph.D. dissertation, Département Ethnologie et Préhistoire, Université Paris-Ouest Nanterre-La Défense, Paris.

Andrieu, Chloé, and Céline Gillot

2008 Estudio de la cantera ubicada al SE del edificio A1. In Proyecto Río Bec (Campeche, México). Informe de la sexta temporada de campo, del 4 de febrero al 3 de mayo de 2007, edited by Dominique Michelet. Instituto Nacional de Antropología e Historia-Centro de Estudios Mexicanos y Centroamericanos. Report on file, Instituto Nacional de Antropología e Historia, Mexico City.

Arnauld, M. Charlotte

2008 Maya Urbanization: Agrarian Cities in a Preindustrial World / Urbanización Maya: Ciudades agrarias en un mundo pre-industrial. In Urbanism in Mesoamerica / El urbanismo en Mesoamerica, Vol. 2, edited by Alba Guadalupe Mastache, Robert H. Cobean, Angel García Cook, and Kenneth G. Hirth, pp. 1-36. Instituto Nacional de Antropología e Historia and the Pennsylvania State University, Mexico City and University Park.

Arnauld, M. Charlotte, and Dominique Michelet

2004 Nature et dynamique des cités Maya. Annales, Histoire, Sciences Sociales 59:73-108.

Arnauld, M. Charlotte, Dominique Michelet, and Philippe Nondédéo

2013 Living Together in Río Bec Houses: Coresidence, Rank, and Alliance. Ancient Mesoamerica 24:469-493.

Arnauld, M. Charlotte, Dominique Michelet, Boris Vannière, Philippe

Nondédéo, and Eva Lemonnier

2012 Houses, Emulation and Cooperation among the Río Bec Groups. The Neighborhood as a Social and Spatial Unit in Mesoamerican Cities, edited by M. Charlotte Arnauld, Linda R. Manzanilla, and Michael E. Smith, pp. 202-228. University of Arizona Press, Tucson. Ashmore, Wendy

1981 Some Issues of Method and Theory. In Lowland Maya Settlement Patterns, edited by Wendy Ashmore, pp. 37-69. University of New Mexico Press, Albuquerque.

Ball, Joseph W., and Richalene G. Kelsay

1992 Prehistoric Intrasettlement Land Use and Residual Soil Phosphate Levels in the Upper Belize Valley, Central America. In Gardens of Prehistory: The Archaeology of Settlement Agriculture in Greater Mesoamerica, edited by Thomas W. Killion, pp. 234-262. University of Alabama Press, Tuscaloosa.

Beach, Timothy P., Sheryl Luzzader-Beach, Nicholas P. Dunning, Jon

Hageman, and Jon Lohse

2002 Upland Agriculture in the Maya Lowlands: Ancient Maya
Déodat, Céline Gillot, Emyly Gonzáles G., and Rosalia Carrillo S. for their suggestions during fieldwork and for their help in interpreting data. The paper was translated by Timothy Seller, with the help of Michelle Elliot, and to both we express our gratitude. We would like to thank also Nicholas Dunning, Scott Fedick, and an anonymous reviewer for their useful comments and suggestions, which greatly helped to improve the manuscript.

Soil Conservation in Northwestern Belize. Geographical Review 92:372-397.

Carrasco Vargas, Ramón, Sylviane Boucher, and Agustín Peña Castillo

1986 Río Bec: Un modelo representativo del patrón de asentamiento regional. Boletín de la Escuela de Ciencias Antropológicas de la Universidad de Yucatan 13(78):20-30.

Chase, Arlen F., and Diane Z. Chase

1998 Scale and Intensity in Classic Period Maya Agriculture: Terracing and Settlement at the "Garden City" of Caracol, Belize. Culture and Agriculture 20(2/3):60-77.

Coe, Michael D., and Kent Flannery

1964 Microenvironments and Mesoamerican Prehistory. Science 143: $650-654$.

Culbert, T. Patrick, Vilma Fialko, Brian McKee, Liwy Grazioso, Julie

Kunen, and Leonel Paez

1997 Investigaciones arqueológicas en el Bajo La Justa, Peten. In $X$ Simposio de Investigaciones Arqueológicas en Guatemala 1996, edited by Juan Pedro Laporte and Hector L. Escobedo, pp. 367-372. Museo Nacional de Arqueología y Etnología, Ministerio de Cultura y Deportes, Instituto de Antropología e Historia, and the Asociación Tikal, Guatemala.

Culbert, T. Patrick, Laura J. Levi, and Luís Cruz

1990 Lowland Maya Wetland Agriculture: The Rio Azul Agronomy. In Vision and Revision in Maya Studies, edited by Flora S. Clancy and Peter Harrison, pp. 115-124. University of New Mexico Press, Albuquerque.

Drennan, Robert D.

1988 Household Location and Compact versus Dispersed Settlement in Prehispanic Mesoamerica. In Household and Community in the Mesoamerican Past, edited by Richard R. Wilk and Wendy Ashmore, pp. 273-293. University of New Mexico Press, Albuquerque.

Dunning, Nicholas P.

1993 Ambiente, patrón de asentamiento y agricultura en las Tierras Bajas Maya durante el periodo Clásico (250-900 d.C.). Apuntes Arqueológicos 3(2):123-134.

2004 Down on the Farm: Classic Maya "Homesteads" as "Farmsteads". In Ancient Maya Commoners, edited by Jon C. Lohse and Fred Valdez Jr., pp. 97-116, University of Texas Press, Austin.

Dunning, Nicholas P., and Timothy P. Beach

1994 Soil Erosion, Slope Management, and Ancient Terracing in the Maya Lowlands. Latin American Antiquity 5:51-69.

Dunning, Nicholas P., Timothy P. Beach, and David Rue

1997 The Paleoecology and Ancient Settlement of the Petexbatun Region, Guatemala. Ancient Mesoamerica 8:255-266.

Dunning, Nicholas P., Leonel Paez, Timothy Beach, and James Nicholas

1993 Investigación de terrazas agrícolas en Petexbatun: Temporada 1993. In Proyecto Arqueológico Regional Petexbatun: Informe Preliminar 5, Quinta Temporada 1993, edited by Juan Antonio Valdés, Antonia Foias, Takeshi Inomata, Héctor Escobedo, and Arthur A. Demarest, pp. 171-182. Instituto de Antropología e Historia and the Department of Anthropology, Vanderbilt University, Guatemala City and Nashville.

Dunning, Nicholas P., Sheryl Luzzadder-Beach, Timothy P. Beach, John G.

Jones, Vernon L. Scarborough, and T. Patrick Culbert

2002 Arising from the Bajos: The Evolution of a Neotropical Landscape and the Rise of Maya Civilization. Annals of the Association of American Geographers 92:267-283.

Eaton, Jack D.

1975 Ancient Agricultural Farmsteads in the Rio Bec Region of Yucatan. Contributions of the University of California Archaeological Research Facility 27:56-82. 
Fedick, Scott L.

1996a The Managed Mosaic: Ancient Maya Agriculture and Resource Use. University of Utah Press, Salt Lake City.

1994 Ancient Maya Agricultural Terracing in the Upper Belize River Area: Computer-aided Modeling and the Results of Initial Field Investigations. Ancient Mesoamerica 5:107-127.

1996b Conclusion: Landscape Approaches to the Study of Ancient Maya Agriculture and Resource Use. In The Managed Mosaic: Ancient Maya Agriculture and Resource Use, edited by Scott L. Fedick, pp. 335-347. University of Utah Press, Salt Lake City.

Fedick, Scott L., Bethany A. Morrison, Bente J. Andersen, Sylviane

Boucher, Jorge Cera Acosta, and Jennifer P. Mathews

2000 Wetland Manipulation in the Yalahau Region of the Northern Maya Lowlands. Journal of Field Archaeology 27:131-152.

Flannery, Kent V.

1982 Maya Subsistence: Studies in Memory of Dennis E. Puleston. Academic Press, New York.

Folan, William J., Ellen R. Kintz, and Loraine Anne Fletcher (eds.)

1983 Coba: A Classic Maya Metropolis. Academic Press, New York.

Gillot, Céline

2010 Operación IVC: Inventario arquitectural y modos de construcción, análisis de las zonas de extracción. In Proyecto Río Bec (Campeche México). Informe de la octava temporada, 2009, edited by Dominique Michelet. Instituto Nacional de Antropología e Historia-Centro de Estudios Mexicanos y Centroamericanos. Report on file, Instituto Nacional de Antropología e Historia, Mexico City.

Gómez Pompa, Arturo, Michael F. Allen, Scott L. Fedick, and Juan J.

Osornio-Jiménez

2003 The Lowland Maya Area: Three Millennia at The Human-Wildland Interface. Food Products Press, Binghamton, New York.

Guilaine, Jean

1991 Pour une archéologie agraire. Armand Colin, Paris.

Guy, Max

1987 Anciens parcellaires quadrillés de la région de Teotihuacan (Mexique). Photo-interprétation: Images Aériennes et Spatiales 26(5/6):57-64.

Harrison, Peter D., and B.L. Turner II (editors)

1978 Pre-Hispanic Maya Agriculture. University of New Mexico Press, Albuquerque.

Hayden, Brian, and Aubrey Cannon

1983 Where the Garbage Goes: Refuse Disposal in the Maya Highlands. Journal of Anthropological Archaeology 2:117-163.

Hodell, David A., Jason H. Curtis, and Mark Brenner

1995 Possible Role of Climate in the Collapse of Classic Maya Civilization. Nature 375:391-394.

Hughbanks, Paul J.

1998 Settlement and Land Use at Guijarral, Northwestern Belize. Culture and Agriculture 20:107-120.

Hutson, Scott R., Aline Magnoni, and Travis W. Stanton

2004 House Rules? The Practice of Social Organization in Classic-Period Chunchucmil, Yucatan, Mexico. Ancient Mesoamerica 15:75-92.

Johnston, Kevin

2003 The Intensification of Pre-industrial Cereal Agriculture in the Tropics: Boserup, Cultivation Lengthening, and the Classic Maya. Journal of Anthropological Archaeology 22:126-161.

Johnston, Kevin, and Andrew Breckenridge

1999 Proyecto de Paleoecología: Reconstrucción de patrones de utilización del terreno y deforestación en el periodo clásico. In XII Simposio de Investigaciones Arqueológicas en Guatemala 1998, edited by Juan Pedro Laporte, Héctor L. Escobedo, and Ana Claudia Monzón de Suasnávar, pp. 235-248. Museo Nacional de Arqueología y Etnología, Ministerio de Cultura y Deportes, Instituto de Antropología e Historia, and the Asociación Tikal, Guatemala City.

Kepecs, Susan, and Sylviane Boucher

1996 The Prehispanic Cultivation of Rejolladas and Stone-lands: New Evidence from Northeast Yucatan. In The Managed Mosaic: Ancient Maya Agriculture and Resource Use, dited by Scott L. Fedick, pp. 69-91. University of Utah Press, Salt Lake City.

Killion, Thomas W. (editor)

1992 Gardens of Prehistory: The Archaeology of Settlement Agriculture in Greater Mesoamerica. University of Alabama Press, Tuscaloosa.
Killion, Thomas W, Jeremy A. Sabloff, Gair Tourtellot, and Nicholas P. Dunning

1989 Intensive Surface Collection of Residential Clusters at Terminal Classic Sayil, Yucatan, Mexico. Journal of Field Archaeology 16: 273-294.

Kunen, Julie L.

2001 Ancient Maya Agricultural Installations and the Development of Intensive Agriculture in NW Belize. Journal of Field Archeology 28: 325-346.

2004 Ancient Maya Life in the Far West Bajo: Social and Environmental Change in the Wetlands of Belize. University of Arizona Press, Tucson.

Lemonnier, Eva

2009 La structure de l'habitat du site Maya classique de La Joyanca (Petén Nord-Ouest, Guatemala) dans son environnement local. Paris Monographs in American Archaeology No. 23. BAR International Series 2016. British Archaeological Reports, Oxford.

Lemonnier, Eva, and M. Charlotte Arnauld

2008 Sistemas clásicos de asentamientos jerarquizados en La Joyanca, Guatemala, y Río Bec, México. In XXI Simposio de Investigaciones Arqueológicas en Guatemala 2007, edited by Juan Pedro Laporte, Bárbara Arroyo, and Héctor Mejía, pp. 227-234. Museo Nacional de Arqueología y Etnología, Ministerio de Cultura y Deportes, Instituto de Antropología e Historia, Asociación Tikal, and the Fundación Arqueológica del Nuevo Mundo, Guatemala City.

Lemonnier, Eva, and Boris Vannière

2008 Operación VIII: Relaciones hombre/medio ambiente en Río Bec. In Proyecto Río Bec (Campeche México). Informe de la sexta temporada, del 4 de febrero al 3 de mayo de 2007, edited by Dominique Michelet. Instituto Nacional de Antropología e Historia-Centro de Estudios Mexicanos y Centroamericanos. Report on file, Instituto Nacional de Antropología e Historia, Mexico City.

2009 Operación IA (seguimiento de la Operación VIII: Relaciones hombre/medio ambiente en Río Bec). In Proyecto Río Bec (Campeche México). Informe de la séptima temporada, del 19 de febrero al 5 de mayo de 2008, edited by Dominique Michelet. Instituto Nacional de Antropología e Historia-Centro de Estudios Mexicanos y Centroamericanos. Report on file, Instituto Nacional de Antropología e Historia, Mexico City.

Leyden Barbara, W., Mark Brenner, Tom Whitmore, Jason H. Curtis,

Dolores R. Piperno, and Bruce H. Dahlin

1996 A Record of Long- and Short-Term Climatic Variation from Northwest Yucatan: Cenote San José Chulchacá. In The Managed Mosaic: Ancient Maya Agriculture and Resource Use, edited by Scott L. Fedick, pp. 30-50, University of Utah Press, Salt Lake City.

Liendo Stuardo, Rodrigo

2002 The Organization of Agricultural Production at a Classic Maya Center: Settlement Patterns in the Palenque Region, Chiapas, Mexico. University of Pittsburgh Press and the Instituto Nacional de Antropología e Historia, Pittsburgh and Mexico City.

Manzanilla, Linda, and Luis Barba

1990 The Study of Activities in Classic Households: Two Case Studies from Coba and Teotihuacan. Ancient Mesoamerica 1:41-49.

Merwin, Raymond E.

1913 The Ruins of the Southern Part of the Peninsula of Yucatan, with Special Reference to Their Place in the Maya Area. Ph.D. dissertation, Department of Anthropology, Harvard University, Cambridge, MA.

Michelet, Dominique

2004 Operación I: Plano del sitio. In Proyecto Río Bec (Campeche Mexique). Informe de la segunda temporada, del 27 de febrero al 25 de mayo de 2003, edited by Dominique Michelet. Instituto Nacional de Antropología e Historia-Centro de Estudios Mexicanos y Centroamericanos. Report on file, Instituto Nacional de Antropología e Historia, Mexico City.

Michelet, Dominique, Philippe Nondédéo, Julie Patrois, Céline Gillot, and Emyly González G.

2013 Structure 5N2 ("Group A”): A Río Bec Paradigmatic Palace? Ancient Mesoamerica 24:415-431.

Netting, Robert McC.

1977 Maya Subsistence: Mythologies, Analogies and Possibilities. In The Origins of Maya Civilization, edited by Richard E.W. Adams, pp. 299-333. University of New Mexico Press, Albuquerque. 
Nondédéo, Philippe (editor)

2002 Proyecto Río Bec (Campeche México). Informe de la primera temporada, del 15 de febrero al 18 de mayo de 2002. Instituto Nacional de Antropología e Historia-Centro de Estudios Mexicanos y Centroamericanos. Report on file, Instituto Nacional de Antropología e Historia, Mexico City.

Nondédéo, Philippe, M. Charlotte Arnauld, and Dominique Michelet

2013 Río Bec Settlement Patterns and Local Sociopolitical Organization. Ancient Mesoamerica 24:373-396.

Peña Castillo, Agustín

1987 Hormiguero y Dos Aguadas: Análisis comparativo de dos sitios en el sur de Campeche. Unpublished Master's thesis, Escuela Nacional de Antropologia e Historia, Mexico City.

Pohl, Mary (ed.)

1990 Ancient Maya Wetland Agriculture: Excavations on Albion Island, Northern Belize. Westview Special Studies in Archaeological Research. Westview Press, Boulder, CO.

Pollock, Harry E.D.

1967 Brainerd y Ruppert en Xpuhil en 1949. Estudios de Cultura Maya 6:67-80.

Pyburn, K. Anne

1998 Smallholders in the Maya Lowlands: Homage to a Garden Variety Ethnographer. Human Ecology 26:267-286.

Rice, Don S.

1993 Eighth-Century Physical Geography, Environment and Natural Resources in the Maya Lowlands. In Lowland Maya Civilization in the Eighth Century A.D., edited by Jeremy A. Sabloff and John S. Henderson, pp. 11-64. Dumbarton Oaks, Washington, DC.

Ringle, William M., and E. Wyllys Andrews V

1988 Formative Residences at Komchen, Yucatan, Mexico. In Household and Community in the Mesoamerican Past, edited by Richard R. Wilk and Wendy Ashmore, pp. 171-198. University of New Mexico Press, Albuquerque.

Robin, Cynthia

2003 New Directions in Classic Maya Household Archaeology. Journal of Archaeological Research 11:307-356.

Ross, Nanci J.

2011 Modern Tree Species Composition Reflects Ancient Maya "Forest Gardens" in Northwest Belize. Ecological Applications 21:75-84.

Ruppert, Karl, and John H. Denison

1943 Archaeological Reconnaissance in Campeche, Quintana Roo and Peten. Carnegie Institution of Washington Publication No. 543, Washington, DC.

Sanders, William T.

1977 Environmental Heterogeneity and Evolution of Lowland Maya Civilization. In The Origins of Maya Civilization, edited by Richard E.W. Adams, pp. 287-297. University of New Mexico Press, Albuquerque.

Smyth, Michael P., Christopher D. Dore, and Nicholas P. Dunning

1995 Interpreting Prehistoric Settlement Patterns: Lessons from the Maya Center of Sayil, Yucatan. Journal of Field Archaeology 22:321-347.

Taladoire, Eric, Sara Dzul, Philippe Nondédéo, and Mélanie Forné

2013 Chronology of the Río Bec Settlement and Architecture. Ancient Mesoamerica 24:353-372.

Thomas, Prentice M., Jr.

1981 Prehistoric Maya Settlement Patterns at Becan, Campeche, Mexico. Middle American Research Institute, Publication No. 45. Tulane University, New Orleans.

Tourtellot, Gair, Francisco Estrada-Belli, John J. Rose, and Norman

Hammond

2003 Late Classic Heterarchy, Hierarchy, and Landscape at La Milpa, Belize. In Heterarchy, Political Economy, and the Ancient Maya: The Three Rivers Region of the Eastern-Central Yucatan Peninsula, edited by Vernon Scarborough, Fred Valdez Jr., and Nicholas Dunning, pp. 37-51. University of Arizona Press, Tucson.
Tourtellot, Gair, Jeremy A. Sabloff, Michael P. Smyth, L. Van Whitley, Stanley T. Walling, Tomas Gallareta Negrón, Carlos Pérez Alvarez, George F. Andrews, and Nicholas P. Dunning

1988 Mapping Community Patterns at Sayil, Yucatan, Mexico: The 1985 Season. Journal of New World Archaeology 7(43):1-24.

Turner II, Billie Lee

1974 Prehistoric Intensive Agriculture in the Maya Lowlands. Science 185:118-124.

1983 Once Beneath the Forest: Prehistoric Terracing in the Rio Bec Region of the Maya Lowlands. Westview Press, Boulder, CO.

Turner, Billie Lee, II, and William T. Sanders

1992 Summary and Critique. In Gardens of Prehistory: The Archaeology of Settlement Agriculture in Greater Mesoamerica, edited by Thomas W. Killion, pp. 263-284. University of Alabama Press, Tuscaloosa.

Vannière, Boris, Christine Heinz, Georges Marchand, and Didier Galop

2006 Operación VIII: Uso del medio ambiente y dinámicas paleo-ecológicas. In Proyecto Río Bec (Campeche México). Informe de la cuarta temporada, del 8 de febrero al 6 de mayo de 2005, edited by Dominique Michelet. Centre National de la Recherche Scientifique and the Instituto Nacional de Antropología e Historia-Centro de Estudios Mexicanos y Centroamericanos, Paris and Mexico City.

Vannière, Boris, Eva Lemonnier, Georges Marchand, Christine Heinz, Laure Saligny, and Agnès Stock

2007 Operación VIII: relaciones hombre/medio ambiente. In Proyecto Río Bec (Campeche México). Informe de la quinta temporada, del 5 de febrero al 4 de mayo de 2006, edited by Dominique Michelet. Centre National de la Recherche Scientifique and the Instituto Nacional de Antropología e Historia-Centro de Estudios Mexicanos y Centroamericanos, Paris and Mexico City.

Vapnarsky, Valentina, and Olivier Le Guen

2011 The Guardians of Space and History: Understanding Ecological and Historical Relationships of the Contemporary Yucatec Maya to their Landscape. In Ecology, Power, and Religion in Maya Landscapes, edited by Christian Isendahl and Bodil Liljefors Persson, pp. 191-206. Verlag Anton Saurwein, Markt Schwaben, Germany.

Wauchope, Robert

1956 Seminars in Archaeology, 1955. Memoirs of the Society for American Archaeology No. 11. The Society for American Archaeology, Salt Lake City, UT.

Webster, David L., AnnCorrine Freter, and Nancy Gonlin (editors)

2000 Copan: The Rise and Fall of an Ancient Maya Kingdom. Wadsworth-Thompson Learning, Bellmont, CA.

Weiss-Krejci, Estella, and Thomas Sabbas

2002 The Potential Role of Small Depressions as Water Storage Features in the Central Maya Lowlands. Latin American Antiquity 13:343-357.

Whitmore, Thomas M., and Billie Lee Turner II

2001 Cultivated Landscapes of Native Middle America on the Eve of the Conquest. Oxford University Press, Oxford.

Wilk, Richard R.

1985 Dry Season Agriculture among the Kekchi Maya and Its Implications for Prehistory. In Prehistoric Lowland Maya Environment and Subsistence Economy, edited by Mary Pohl, pp. 47-57. Papers of the Peabody Museum of Archaeology and Ethnology Harvard University, Vol. 17. Harvard University, Cambridge, MA.

Willey, Gordon R. (editor)

1956 Prehistoric Settlement Patterns in the New World. Viking Fund Publications in Anthropology No. 23. Wenner-Gren Foundation for Anthropological Research, New York.

Willey, Gordon R., William R. Bullard, John B. Glass, and James C. Gifford 1965 Prehistoric Maya Settlement in the Belize Valley. Papers of the Peabody Museum of Archaeology and Ethnology, Vol. 54. Harvard University, Cambridge, MA. 